OPEN ACCESS

Edited by:

Markus A. N. Hartl,

University of Innsbruck, Austria

Reviewed by: Ugo Moens,

UiT the Arctic University of

Norway, Norway

Abhik Saha

Presidency University, India

*Correspondence:

Mauro Tognon

tgm@unife.it

Fernanda Martini

mrf@unife.it

Specialty section

This article was submitted to

Molecular and Cellular Oncology,

a section of the journal

Frontiers in Oncology

Received: 25 March 2019

Accepted: 09 July 2019

Published: 25 July 2019

Citation:

Rotondo JC, Mazzoni E, Bononi I,

Tognon M and Martini F (2019)

Association Between Simian Virus 40

and Human Tumors.

Front. Oncol. 9:670

doi: 10.3389/fonc.2019.00670

\section{Association Between Simian Virus 40 and Human Tumors}

\author{
John Charles Rotondo, Elisa Mazzoni, Ilaria Bononi, Mauro Tognon* and \\ Fernanda Martini*
}

Section of Pathology, Oncology and Experimental Biology, Department of Morphology, Surgery and Experimental Medicine, University of Ferrara, Ferrara, Italy

Simian virus 40 (SV40) is a small DNA tumor virus of monkey origin. This polyomavirus was administered to human populations mainly through contaminated polio vaccines, which were produced in naturally infected SV40 monkey cells. Previous molecular biology and recent immunological assays have indicated that SV4O is spreading in human populations, independently from earlier SV40-contaminated vaccines. SV40 DNA sequences have been detected at a higher prevalence in specific human cancer specimens, such as the brain and bone tumors, malignant pleural mesotheliomas, and lymphoproliferative disorders, compared to the corresponding normal tissues/specimens. However, other investigations, which reported negative data, did not confirm an association between SV40 and human tumors. To circumvent the controversies, which have arisen because of these molecular biology studies, immunological researches with newly developed indirect ELISA tests were carried out in serum samples from patients affected by the same kind of tumors as mentioned above. These innovative indirect ELISAs employ synthetic peptides as mimotopes/specific SV40 antigens. SV40 mimotopes do not cross-react with the homologous human polyomaviruses, BKPyV, and JCPyV. Immunological data obtained from indirect ELISAs, using SV40 mimotopes, employed to analyze serum samples from oncological patients, have indicated that these sera had a higher prevalence of antibodies against SV40 compared to healthy subjects. The main data on (i) the biology and genetics of SV40; (ii) the epidemiology of SV40 in the general population, (iii) the mechanisms of SV40 transformation; (iv) the putative role of SV4O in the onset/progression of specific human tumors, and (v) its association with other human diseases are reported in this review.

Keywords: simian virus 40, polyomavirus, cancer, tumor, malignant pleura mesothelioma, osteosarcoma, healthy subjects, ELISA

\section{INTRODUCTION}

Simian virus 40 (SV40) is a monkey virus that was accidentally administered to human populations through SV40-contaminated vaccines, mainly polio vaccines, between 1955 and 1963 (1). SV40 has been assigned to the family of Polyomaviridae, Betapolyomavirus genus, which is closely related to human JC (JCPyV) and BK (BKPyV) polyomaviruses (HPyVs) (2). Many studies have reported on the transforming and tumorigenic properties of SV40, which have been experimentally proven in cell cultures and animal models, respectively (3-7). These data have encouraged a significant amount of new researches aimed developed aimed at verifying if an association between SV40 and different human cancers exists. 
This review provides a brief overview on the (i) biology and genetics of SV40; (ii) the epidemiology of SV40 in the general population, (iii) the mechanisms of SV40 transformation; (iv) the putative role of SV40 in the onset/progression of specific human tumors, and (v) its association with other human diseases.

\section{SV40 GENOMIC ORGANIZATION}

The SV40 virion is formed by an unenveloped icosahedral protein structure with a diameter of $45-50 \mathrm{~nm}$ and a density of $1.34-1.35 \mathrm{~g} / \mathrm{cm}^{3}$ (8). Its viral genome is a circular doublestranded DNA molecule with $\sim 5.2 \mathrm{~kb}$, depending on the SV40 strain (9). SV40 shares about 70-75\% genome homology with JCPyV (10-12) and BKPyV (12, 13), whereas it has little homology with other HPyVs, including HPyV 6 and 7 (14), Malawi polyomavirus (MXPyV or HPyV 10) (15), Saint Louis polyomavirus (STPyV or HPyV 11) (16), and Merkel cell polyomavirus (MCPyV) (17-19).

Three main regions have been identified in the SV40 genome: (i) a non-coding control region (NCCR), (ii) an early, and (iii) late coding regions (Figure 1). NCCR includes the DNA replication origin (ori) and a gene promoter, whose nucleotide sequences are binding sites for transcription factors regulating early and late gene expressions. The terms "early" and "late" indicate the chronological order of gene transcriptions during the viral life cycle in the host cell. Both early and late genes are transcribed in opposing directions, i.e., anti-clockwise and

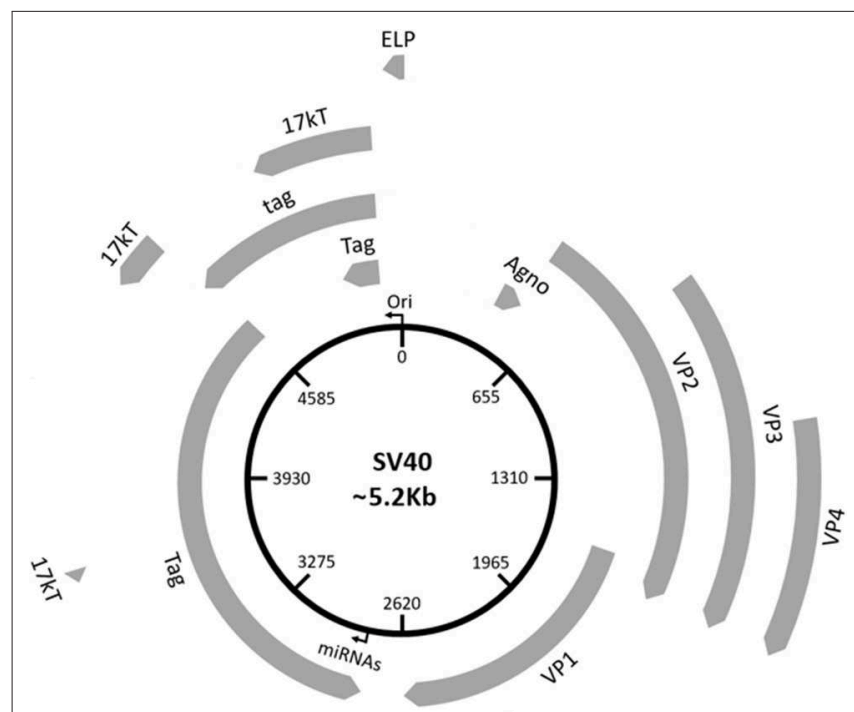

FIGURE 1 | Schematic representation of the SV40 genome. SV40 DNA is made up of three regions: the regulatory region and the early and late regions. The regulatory region contains the origin of replication (ori) and regulates the viral gene expression. The early region contains coding sequences for early genes, including the large tumor $\mathrm{T}$ antigen (Tag), the small tumor $\mathrm{t}$ antigen (tag), $17 \mathrm{kT}$, and the early leader protein (ELP). The late region contains coding sequences for late genes, including the major capsid protein VP 1, the VP 2, VP 3, VP 4, and the agnoprotein (Agno). The two miRNAs maps within the Tag gene sequences. clockwise, respectively, in relation to NCCR. The early region contains coding sequences for the large tumor antigen (Tag), small tumor antigen (tag), $17 \mathrm{kT}$ and the early leader protein (Figure 1, Table 1). Both Tag and tag are transcribed with alternative splicing. Tag and tag are viral oncoproteins, which induce SV40 DNA replication, gene expression, as well as S-phase entry and DNA synthesis in the host cell, thereby triggering cycle progression (Figure 2) (9). In addition, these two oncoproteins own transformation potential in vitro and exert oncogenic activities in vivo (9). The $17 \mathrm{kT}$ protein, which shares most of its amino acid (aa) sequence with the Tag Nterminal domain, promotes cell cycle progression in the presence of tag, as well as presenting tumorigenic potential (20). The early leader protein is a small protein of 23 aa whose function is unclear (21). The late region contains genes transcribed into two classes of late mRNAs: (i) 16S, which encodes the major capsid protein VP 1; (ii) 19S, coding for the VP 2, VP 3, VP 4 polypeptides, and the agnoprotein (Figure 1, Table 1). VP 1-23 are structural proteins that enable viral DNA to be packaged into the SV40 virion. A total of 360 VP 1 molecules form, with 72 pentamers, the virion $(22,23)$. The internal face of each pentamer binds a single copy of VP 2 or VP 3 (22). VP 4 seems to facilitate the lytic release of the SV40 virions (24), but a recent study demonstrated that VP4 is not required for this process (25). The agnoprotein controls the perinuclear localization of VP 1 during virion formation, which then triggers virion assembly (26). In total, SV40 translates for nine proteins. Recently, two SV40-encoded microRNAs (miRNAs) have been identified (Figure 1, Table 1) (27). More details are reported on this topic in the section "SV40 microRNAs and viral infection" (see below).

\section{SV40 LIFE CYCLE}

Attachment of the SV40 viral capsid to the target cell surface is the first event to take place during the infection process

TABLE 1 | SV40 gene products.

\begin{tabular}{|c|c|c|}
\hline & $\begin{array}{l}\text { SV40 expression } \\
\text { products }\end{array}$ & Main function(s) \\
\hline \multirow[t]{6}{*}{ Early } & Large tumor T antigen (Tag) & $\begin{array}{l}\text { Cell cycle progression, viral DNA } \\
\text { replication }\end{array}$ \\
\hline & Small tumor $t$ antigen (tag) & $\begin{array}{l}\text { Cell cycle progression, viral DNA } \\
\text { replication }\end{array}$ \\
\hline & $17 \mathrm{KT}$ & Cell cycle progression \\
\hline & Early leader protein & Unclear function \\
\hline & Early polarity SVmiRNA & Tag regulation \\
\hline & $\begin{array}{l}\text { Late polarity SVmiRNA Tag } \\
\text { regulation }\end{array}$ & \\
\hline \multirow[t]{5}{*}{ Late } & VP1 & $\begin{array}{l}\text { Capsid structure (external), viral } \\
\text { attachment and entry }\end{array}$ \\
\hline & VP2 & Capsid structure (internal) \\
\hline & VP3 & Capsid structure (internal) \\
\hline & VP4 & Cell lysis, viral particles release \\
\hline & Agnoprotein & Virion assembly \\
\hline
\end{tabular}




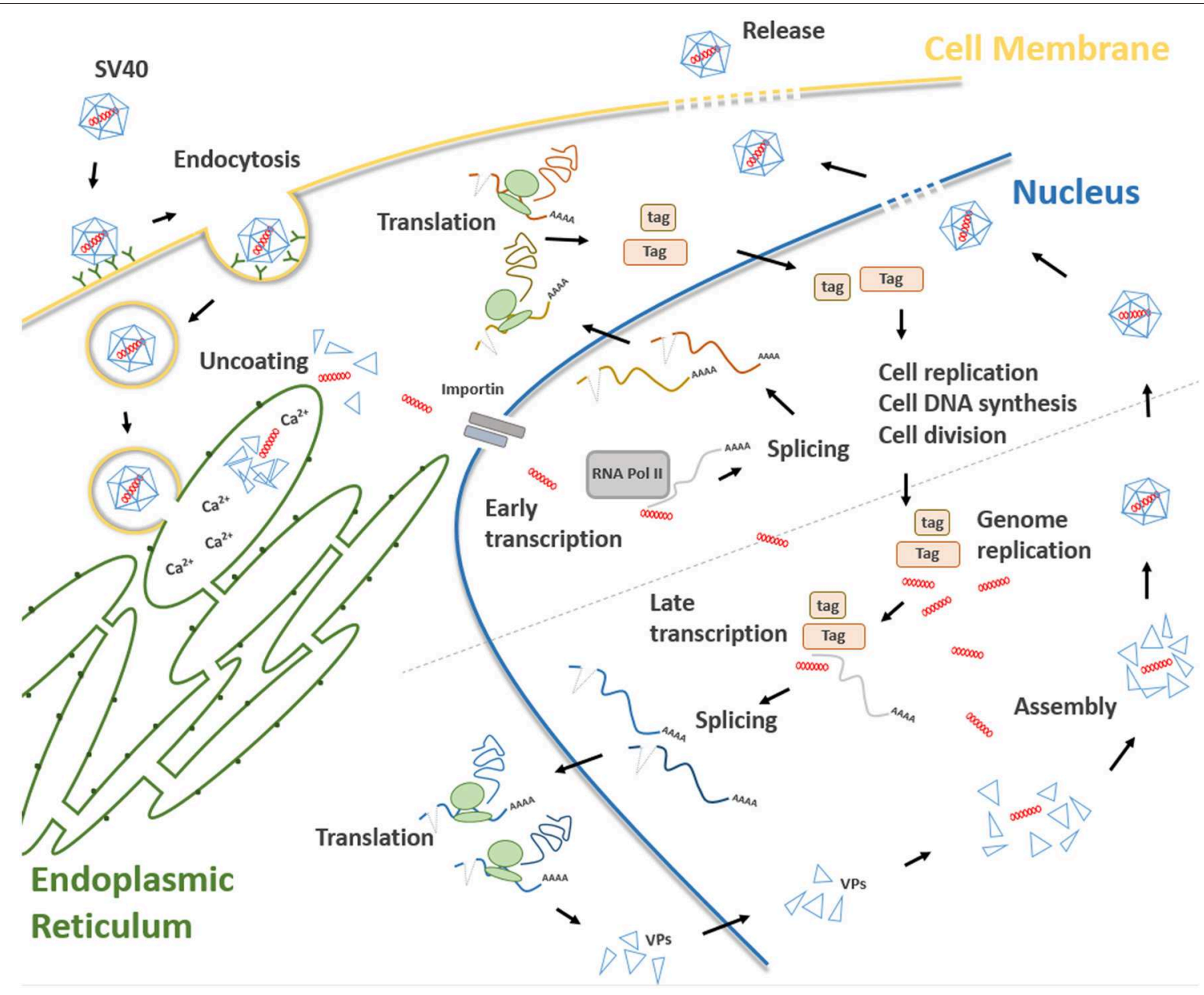

FIGURE 2 | Main steps of the SV40 life cycle. The life cycle of SV40 starts with the attachment of the SV40 viral capsid to the target cell surface and proceeds through a lipid raft-mediated endocytosis. Then, the virion is transferred, by vesicular transport, toward the endoplasmic reticulum where it starts the uncoating process which continues in the cell cytosol. Uncoated SV40 genomes translocate inside the nucleus where the cellular RNA polymerase II mediates early viral transcription. Early transcription generates a precursor that is alternatively spliced into mRNAs, encoding the large T (Tag), and small t (tag) antigens. These mRNAs are translated in the cytosol into their corresponding proteins. Tag and tag migrate to the nucleus where they mediate several functions interfering with a number of host cellular pathways, thereby forcing the cells to proceed from the G1 to the S-phase. At the same time, Tag/tag starts the replication of the SV40 genome. The transition from early to late phase during the SV40 infection begins at the end of the viral DNA replication. After synthesis, late viral proteins are accumulated in the cytoplasm, migrates into the nucleus and then assemble with replicated viral DNA to form virions. Finally, a progeny virus is released through cell lysis.

in host cells. Binding is mediated by an interaction between VP 1, the cell surface receptor ganglioside GM1 (28), and the major histocompatibility complex (MHC) class I, that act as co-receptors (29). Afterwards, SV40 capsid enters the target cell via lipid raft-mediated endocytosis (30), which is triggered by the interaction between VP 1 and cell surface ganglioside GM1 (31) (Figure 2). Then, SV40 capsid is transferred, by vesicular transport, in the endosomal compartment, toward the endoplasmic reticulum (ER). In atypical circumstances, SV40 enters the cells via a caveolae-mediated endocytic pathway by which the virus is directly translocated to the ER (32, 33), bypassing the endosomal compartment. The uncoating process begins in the ER, proceeds through ER absorption of $\mathrm{Ca}^{2+}$ ions, thus inducing the loss of specific inter-pentamer connections provided by invading VP 1 C-terminal arms in the capsid. This process exposes the SV40 nuclear localization signal, thereby inducing the translocation of the viral genome in the nucleus via a mechanism mediated by the importin $\alpha_{2} / \beta$ heterodimer and VP $3(8,34,35)$ (Figure 2). Both early viral transcription and DNA replication occur inside the nucleus. Transcription is NCCR regulated (36), whereas DNA replication starts from the ORI sequence contained in the same NCCR region. SV40 DNA replication occurs soon after transcription in the early region, whereas late region transcription initiates after replication of viral DNA (37). Both early and late promoters are recognized by cellular RNA polymerase II and host factors, thereby inducing viral gene transcription. Early transcription provides the generation of a precursor that is alternatively spliced into two mRNAs encoding Tag and tag (38) (Figure 2). In this phase, SV40 late genes are maintained silenced by 
transcriptional repressors (39). In permissive cells, the role of Tag is essential for DNA replication. Tag is a multifunctional phosphoprotein that binds as a double hexamer to the SV40 viral replication ORI, where it unwinds viral DNA. This molecular process induces cellular protein recruitment required for viral DNA replication, including DNA polymerase- $\alpha$ and replication protein A $(40,41)$. Tag is also responsible for an ATPase activity that is required for viral DNA elongation (42). SV40 needs additional cellular co-factors for its DNA replication, mainly expressed during the $\mathrm{S}$ phase. For this reason, Tag is evolutionarily developed to modulate intracellular proteins involved in crucial signal transduction pathways that control cell cycle progression and apoptosis (43), such as hepatocyte growth factor receptor (HGFR/Met) (44), insulin-like growth factor 1 (IGF-1) (45), Notch-1 (46), and cdc2 (47). These molecules force SV40-infected cells to proceed from the G1 to the S-phase (48). In this mechanism, tag seems to play a cooperative role with Tag in both SV40 DNA replication and S-phase progression (Figure 2) $(7,49,50)$. The transition from the early to late phase, during the SV40 infection, begins at the end of the viral DNA replication. It seems that this early-to-late transcriptional switch depends on changes on Tag concentration. Initially, low Tag concentrations are sufficient for an interaction between high-affinity NCCR Tag-binding motifs and Tag and thus early transcription is positively regulated. Then, high Tag concentrations enable this protein to interact with lowaffinity NCCR Tag-binding motifs. This interaction induces the repressing early transcription by blocking the RNA polymerase II complex. In addition, cellular repressors are titrated-off the late promoter allowing the expression of late genes. Indeed, since the number of SV 40 genomes increases during viral DNA replication, the concentration of repressors is reduced in the late promoter. Tag, together with host transcription factors, interacts with the late promoter, thereby inducing late gene transcription (51). Late genes are transcribed in an opposite direction to the early gene-encoding strand. Late proteins are translated from two classes of late mRNAs: (i) 16S, which encodes the major capsid protein VP 1; (ii) 19S, coding for VP 2, VP 3 , VP 4 polypeptides, and agnoprotein (52) (Figure 2). After synthesis, late viral proteins are accumulated inside the cell via checkpoint kinase Chk1 activation by SV40, which negatively regulates cell mitosis (53). Then, structural proteins assemble with replicated viral DNA to form virions inside the nucleus (Figure 2) (26). This mechanism is induced by the six tandem GC-boxes within the SV40 genome, which represent the capsid assembly signal. Viral assembly starts with GC-boxes interacting with cellular transcriptional factor SP1 recruiting VP 2 and VP 3 , which in turn bind to VP 1 pentamers (54). During this process, the number of capsomers surrounding the viral DNA increases until virion assembly has ended (9). At the same time, the agnoprotein controls perinuclear VP 1 localization (26). Then, the viral particle releasing (Figure 2) leads to cell lysis and necrosis. However, the release of SV40 without displaying a cytopathic effect (CPE) has been reported in specific cell types, such as human mesothelial, epithelial, fibroblasts, and/or embryonic kidney cells (HEK) (44, 55-57).

\section{SV40-MEDIATED CELL IMMORTALIZATION AND TRANSFORMATION}

Mammalian cells of different histotypes behave toward SV40 infection in different ways, depending on the ability of this oncogenic polyomavirus (PyV) to complete the viral cycle and produce a mature viral progeny. SV40-infected cells can be (i) permissive, (ii) non-permissive, or (iii) semi-permissive (56, 5860). The main discriminant depends on viral DNA replication potential expressed in permissive and semi-permissive cells. In this case, viral progeny is produced, whereas SV40 infected cells lyse and die. CV-1 and fibroblast-like COS cell lines, both derived from monkey kidney tissue, are the prototype of permissive cells $(58,61)$. In non-permissive cells, no productive viral cycle is established, whereas the infection occurs but is abortive. Indeed, these cells are transformed/immortalized by SV40. A typical example of non-permissive cells are rodent cells, that carry SV40 DNA integrated in their genome, while cells are transformed (62). Semi-permissive cells allow SV40 multiplication, but they produce a limited viral progeny (63). The majority of cells lyse and die upon infection, but a fraction of cells, which resist the SV40 infection, are transformed and immortalized, while producing a viral progeny at low titer. Several SV40 transformed/immortalized human fibroblasts have been described in the literature $(64,65)$. Cells differ in response to SV40 infection depending on the ability of Tag to stimulate late promoter transcription, which only occurs in permissive/semipermissive cells. Human cells support SV40 replication less efficiently than monkey cells. Different in vitro cellular models have been established to demonstrate the replicative potential of SV40 in human cells (66). Early studies have shown that SV40 can replicate in human fetal neural cell lines (4), mesothelial cells (56), and B-/T-lymphocytes $(64,65,67)$. Although less efficiently, this PyV can also replicate in human HEK lymphoblastoid Bcell lines, as well as fibroblasts, such as WI-38 cells (57, 68$71)$. In addition, in rare cases $\left(<1 / 10^{8}\right.$ cells), human fibroblasts may become transformed due to the viral DNA integration in the host cell genome (72). Early works have shown that one out of seven human astrocytes could become transformed (73) establishing continuous cell lines (74). In addition, several SV40 infected human cells produce a viral progeny at low titer without displaying CPE $(44,56,57)$. An example is provided by normal human mesothelial cells (HMC), which seem to be persistently infected by SV40 for a long period of time, while releasing viral progeny $(44,56,57)$. The molecular mechanism behind the capacity of SV40 to enter into a true persistent/latent state remains to be fully elucidated. It has been reported that SV40 is able to establish a persistent infection in long-term immortalized human fibroblasts, resulting in the production of infectious viral progeny, which is able to infect both monkey and human cells $(64,65)$.

As for other DNA tumor viruses $(75,76)$, several in vitro cellular models have been developed to study SV40 transformation potentials. Tag and tag expression both cause high cell transformation efficiently (3). Indeed, Tag blocks the activities of many different cellular factors involved in cell 


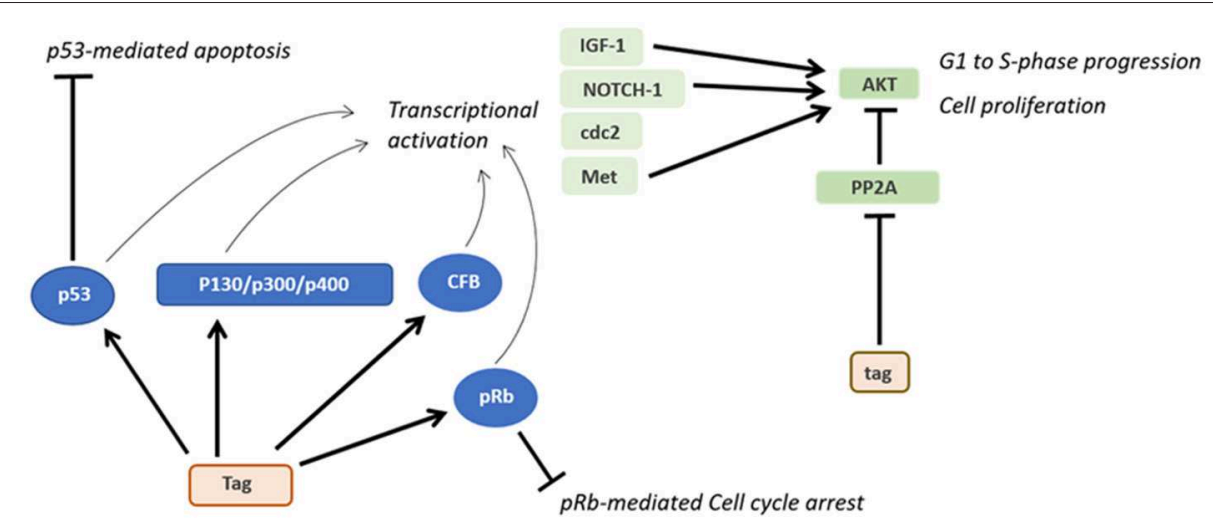

FIGURE 3 | Oncogenic activities of Tag and tag. During SV40 infection, Tag inhibits both the pRB and p53 tumor suppressor pathways. The main downstream effects of these interactions are the blocking of p53-mediated apoptosis and pRb-mediated cell cycle arrest. Furthermore, the interaction between Tag and pRB, p53 and other factors transactivates genes such as IGF-1 and Met, thereby triggering the transition from the G1 to the S-phase and the proliferation of SV40-infected cells. By inhibiting PP2A, tag activates pathways facilitating cell proliferation and transformation.

growth, differentiation and the cell cycle, such as p130, p300, and p400 (Figure 3) (9). In addition, both Tag and tag can inhibit the activities of $\mathrm{p} 53$ and $\mathrm{pRb}$, which are two key tumor suppressor proteins of animal and human cells (9). These interactions are mandatory in order to achieve full human cell transformation (9). Similarly, the transformation potential of Tag belonging to another PyV, MCPyV, has been demonstrated. Indeed, MCPyV Tag or LT has been detected to be overexpressed on MCPyVpositive tumor tissues (17) and several in vitro studies evaluated its transforming activity $(77,78)$. However, it is important to point out that many studies, while reporting the presence of SV 40 sequences in human tumors, did not show the Tag expression. On the other hand, in investigations based on IHC staining of human tumor tissues, the Tag expression was revealed in SV40-positive cells (79-85).

Interestingly, p53 was discovered for the first time when detected bound to Tag in SV40-transformed cells during immunoprecipitation experiments (86). Both Tag and tag can interfere with many other host cellular pathways $(38,87,88)$. For instance, Tag has been found to be associated with many cellular factors, such as Hsc70, Cul7, Bub1, TEF-1, Nbs1, and Fbw7 (59). It has also been reported that the Tag-p53 complexes bind and activate IGF-1 promoter stimulating cell growth (45). The expression of other growth factors may be potentially influenced by Tag (9). Another cellular factor that interacts with Tag during SV40 infection is the hepatocyte growth factor receptor (HGFR or Met) (44). Furthermore, Tag is capable of inducing cell immortalization and transformation by increasing CBP/p300 and specific histone acetylation levels (89).

Upon interaction with the cellular genome and cell factors, SV40 Tag induces different molecular changes in the host cell. SV40 Tag possesses clastogenic and mutagenic activities, which are shown by the appearance of chromosome aberrations and point mutations in the host genome (9093). These molecular/chromosome changes have not been investigated/reported in human tumors presumably caused by SV40. Specific genome alterations are characterized by numerical and structural chromosomal aberrations, such as gaps, breaks, dicentric and ring chromosomes, chromatid changes, deletions, duplications, and translocations (91-93). SV40 Tag favors the accumulation of point mutations, interfering with host DNA repairs pathway $(90,94,95)$. Indeed, SV40 Tag binds p53 protein thereby inhibiting p53-induced apoptosis and allowing DNA-mutated cells to survive $(90,94,95)$. It is well-established that specific chromosomal aberrations can be detected in human tumors of different histotypes, as reported in: (http:// atlasgeneticsoncology.org/Deep/CancerCytogenet2005ID20050. html). In SV40-driven/positive human tumors, a similar panel of chromosome alterations could be displayed (90-93). Occasionally, SV40 DNA integrates into the host cellular genome. This event can occur randomly in the cellular DNA, while the viral DNA breaks randomly, as well (96). In cases where SV40 DNA integration occurs, while maintaining Tag and tag expression, these two viral oncoproteins support the cell transformation phenotype (9). In addition, Liu and collaborators demonstrated that the disruption of the human chromosomal interval at 1q21.1 by SV40 integration, in the human bronchial epithelial cell line, immortalized with a cloned Ori-SV40, CRL-2504 cell line, can be an essential step for cellular immortalization, altering the expression of genes involved in senescence/apoptosis, which are located in the proximity of viral integration sites (97). Integration of SV40 DNA within the human genome has been reported in osteosarcoma samples, thus suggesting that the viral DNA integration is involved the tumorigenic process (98). Altogether these SV40-driven alterations represent the genetic background, which drives the phenotypical changes that lead to the SV40-induced transformation process of the host cell.

The small tag viral oncoprotein interacts with the protein phosphatase $2 \mathrm{~A}$ (PP2A), thereby triggering several pathways related to cellular transformation (Figure 3). The complex tagPP2A induces the entry on the cell cycle S-phase through CDK inhibitor p27 degradation and cyclin A/CDK2 and cyclin E/CDK2 promotion (99-101). Furthermore, tag-PP2A induces 
MAPK cascade activation, thereby triggering the transforming process in vitro (102). The third SV40 early protein, $17 \mathrm{kT}$, also transactivates the cyclin A/CDK2 (100). Although many factors responsible for SV40 transformation have been discovered, the total number of proteins involved in this activity is yet to be determined.

An association between SV40 infection and DNA methylation of different cellular genes has been reported. Indeed, improper DNA methylation is involved in different diseases $(103,104)$, including cancer $(105,106)$. DNA methylation is induced by DNA tumor viruses in order to evade antiviral immunity, which contributes to the immunosuppressive microenvironment during cancer development (107). This process facilitates viral multiplication/activity (107).

In early studies, SV40 transforming potential was largely employed in developing different in vitro cellular models. SV40-immortalized cells have been established and used to study a large number of different molecular mechanisms, including cell proliferation and transformation (108-110), cytokine-production (111), and angiogenesis (112), as well as mesenchymal stem cell differentiation (113) and neuronal differentiation and neuroregeneration (114). Moreover, different diseases, such as autoimmune disorders (115), male infertility (116), fibrosarcoma (108), and corneal dystrophy (117) have been studied employing SV40-immortalized cell models. Other applications of SV40-immortalized cell in vitro models are represented by cellular co-culturing (118) and suicide gene therapy (119).

\section{SV40 MICRORNAs AND VIRAL INFECTION}

MicroRNAs (miRNAs) are small non-coding RNAs [18-22 nucleotides (nt)] that are involved in the post-transcriptional negative regulation of gene expression in eukaryotes (120). These small molecules and their regulatory effect have been described in both eukaryote cells and viruses, including PyVs (120). In the SV40 the early region maps a gene encoding for two miRNAs (Figure 1), which are transcribed in opposite orientations. These two viral miRNAs negatively regulate early mRNAs inhibiting Tag translation through RNA-mediated interference (RNAi) machinery, during the late phase of the SV40 life cycle. These two miRNAs actively direct Tag mRNA cleavage at different nucleotide positions $(27,121)$. However, the silencing potential of human genes by SV40 miRNAs cannot be ruled out $(27,121)$. These findings indicate that SV40 is able to use human RNAi machinery to its own advantage. Since Tag is a target for host cytotoxic T lymphocyte (CTL), the viral miRNA-mediated downregulation of Tag decreases the susceptibility of SV40-infected cells to CTLs activity $(27,121)$. Similarly, JCPyV and BKPyV escape the innate and adaptive immune detection exploiting the human RNAi machinery. Indeed, these two HPyVs code for a miRNA identical in sequence between BKPyV and JCPyV, which targets a member of the UL16 binding protein (ULBP) family, the stress-induced ligand ULBP3 (122). Although a recent study indicates that another member of this gene family, ULBP1, is down-regulated following SV40 infection, it has been demonstrated that SV40 miRNAs do not mediate this molecular effect, thus suggesting the involvement of other mechanisms behind the SV40 immune evasion ability (123). Another report showed that the two SV40 miRNAs can negatively regulate the degree of viral effects on B-cells as demonstrated using SV40 miRNA-null mutants in experiments with infected Blymphocytes and myeloid cell lines (124).

\section{SV40 ONCOGENICITY IN ANIMAL MODELS}

SV40 is a high oncogenic small DNA tumor virus. However, this $\mathrm{PyV}$ has not been reported in tumors of the rhesus macaque (Macaca mulatta), which is its natural host. Indeed, SV40 infection in permissive monkey cells derived from kidney tissues leads to cell lysis and death, without neoplastic transformation $(58,61)$. By contrast, SV40 experimentally inoculated in hamsters induces tumors of different histotypes, depending of the route of injection. Specifically, SV40 subcutaneously (s.c.) inoculated in hamsters induces sarcomas and osteosarcomas; whereas when injected intracerebrally (i.c.) it induces ependymomas and choroid plexus papillomas $(5,38)$. Hematological malignancies, such as lymphocytic leukemia, histiocytic lymphomas, and B-cell lymphomas are induced when SV40 is inoculated intravenously (i.v.) $(5,6)$. SV40 injected in the pleural space of hamsters induces MPM in $100 \%$ of animals (125).

SV40 oncogenic activity is shown in transgenic mice, where $\mathrm{Tag} / \mathrm{tag}$ expression is under the control of its promoter (126) or tissue-specific promoters (127-145). Exploiting the vast SV40 oncogenicity in vivo, SV40 transgenic animals provided good models for studying tumor initiation/progression and innovative anti-cancer therapies (146). Transgenic animals develop ependymomas, choroid plexus papillomas (147), hepatocellular carcinomas $(139,144)$, brain (148), bladder (140), and bowel tumors (149), as well as eye tumors, including ocular and/or lens tumors (150). The multistage progression of prostate carcinoma has also been largely studied employing SV40transgenic mice (128-130, 132, 134-136, 151, 152). Interestingly, transgenic mice generated with SV40 have also been employed to study rare cancers, such as brown adipose tumor (151), cardiac rhabdomyosarcoma (142) and adrenocortical carcinoma (151). Lung cancers and MPM have also been studied in these animal models $(127,137,141)$. More recently, SV40-transgenic mice have been developed to study chronic lymphocytic leukemia (143). In addition, other SV40-transgenic mouse models have also been developed to study fibrosarcoma (108) and retinoblastoma (153) as well as breast $(154,155)$ ovarian $(131,156,157)$, pancreatic $(158)$, and liver cancers $(20,159)$.

\section{EPIDEMIOLOGY OF SV40 INFECTION IN HUMAN POPULATIONS}

SV40 infection in human populations has been widely reported (160-164). Since SV40 is a monkey virus and the macaque is its natural host, this viral infection in humans was considered a rare event, being restricted to subjects in close contact with monkeys. Indeed, inhabitants of Indian villages located near the jungle, 
which is the natural environment for monkeys, and workers attending to monkeys in zoos/animal facilities are prone to SV40 infection and develop antibodies against this PyV $(165,166)$.

SV40 was inadvertently administered to humans between 1955 and 1963, when hundreds of millions of people in North and South America, Canada, Europe, Asia, and Africa were vaccinated with both inactivated and/or live polio vaccines, found to be contaminated by SV40. This accident occurred because these early polio vaccines were produced by growing polioviruses in naturally SV40-infected monkey cell cultures (167-169). It has been reported that in the former USSR, SV40-contaminated polio vaccines were used until 1978 (170), whereas in Italy up to 1999, when the Italian Health Public Organization switched to SV40-free anti-polio vaccines as indicated by the World Health Organization (WHO) guidelines, following a note from the British National Institute for Biological Standards and Control $(9,74,171)$. In other countries, the risk of SV40 contagion through polio vaccines is still a problem, as these vaccines are produced using SV40-positive monkey cells (170). The past literature indicates that SV40 infection in different geographic regions was influenced by the use of either SV40-contaminated or non-contaminated vaccines, as well as the number of years of vaccine administration. Sweet and colleagues quantified that about $10-30 \%$ of polio vaccines were contaminated with SV40 (1). Furthermore, SV40 genotypes in polio vaccines overlap with those detected in humans, thus suggesting that this oncogenic PyV was introduced into the human population through contaminated polio vaccines (172). It has also been reported that shortly after SV40 infection, this PyV spread for weeks in the stools of children vaccinated with SV40-contaminated vaccines (173). This evidence indicates that SV40 replicates in some gastrointestinal cells, thus suggesting that this virus could spread in humans via horizontal infection, such as the fecal-oral route. To a lesser extent, other vaccines against adenoviruses (174) and hepatitis A (175), were SV40 contaminated. In addition, SV40contamination was detected in the respiratory syncytial virus vaccine employed in infected-volunteers to whom the vaccine was given to via the respiratory route (176). About two out of three volunteers developed neutralizing antibodies against SV40 (176). Altogether these data indicate that SV40 infects and multiplies in humans.

Over the years, with the development of molecular biology techniques $(12,18,76,177,178)$, SV40 DNA sequences have been investigated and detected in both normal and neoplastic tissues from individuals vaccinated with polio vaccines contaminated with SV40. DNA sequences from this PyV have been detected in pituitary tissues (179) as well as in leukocytes from organ (180) and blood (181) donors. Footprints from SV40 DNA have also been reported in lymphoblastoid cells (68), as well as blood sample specimens from normal individuals and oncologic patients $(79,161,182-186)$. In addition, SV40 DNA has been detected in blood samples from healthy individuals exposed to asbestos pollution (187). These data cumulatively demonstrate that SV40 is circulating in the human population. It is also possible that blood cells are the SV40 reservoir and vehicle of the virus spreading in humans. Genomic sequences from this $\mathrm{PyV}$ have also been found in stool samples and urine from children and adults, suggesting that SV40 can potentially be transmitted via different routes, such as sexual and fecal-oral routes which are responsible for viral horizontal infection in humans (164, $183,188)$. These additional sources of exposure may lead to subclinical SV40 infections in the healthy population. However, it has been reported that the SV40 transmission in monkeys seems to occur in the environment rather than directly among animals (189). It is plausible that in humans, a contaminated environment or home setting is responsible for SV40 spreading, rather than person to person transmission (188). The site of SV40 latent infection in humans is yet to be elucidated. Since this PyV has been detected in human kidney and urine samples $(183,184)$ it seems reasonable that kidneys might be the site of virus latency, as in monkey it occurs to be the natural host $(1,189)$.

SV40 primary infection occurs early in life and its seroprevalence increases with age. Anti-SV40 antibodies in the serum of immunized individuals and SV40 antigens have been detected in normal subjects (190-199). Lusting et al. reported a prevalence of serum anti SV40 antibodies in 7.6-14\% of Swedish children aged from 1 to 13 years old (198). In early studies, a low prevalence, $11 \%$, was detected in healthy individuals from Africa (200) and the U.S (201). Similarly, a more recent study detected anti SV40 antibodies in sera from healthy adult blood donors with low rates, about 2\% (202). Altogether these serological data indicate that SV40 is present in immunized healthy populations in the range of $1.3-15.6 \%$, suggesting that this PyV circulates in humans at low prevalence (200, 201, 203-206). Interestingly, one study reported SV40 antibodies in human sera before the introduction of SV40contaminated polio vaccines, suggesting that SV40 was probably circulating in humans independently from SV40-contaminated vaccines (207). However, this study was conducted before the identification of human PyVs, JCPyV, and $\mathrm{BKPyV}$, which are highly homologous to $\operatorname{SV} 40(2,13)$. Indeed, the high homology among the three PyVs, BKPyV, JCPyV, and SV40, hampered serological data due to antigenic cross-reactivity. For many years, PyV cross-reactivity did not allow the verification of the real SV40 prevalence in humans (208). Different immunological assays based on the use of virions, soluble recombinant VP 1 protein and virus-like particles (VLPs), such as SV40 antigens, always gave cross-reactivity with BKPyV/JCPyV (208).

In order to circumvent this technical issue, in recent years specific and sensitive indirect ELISA tests with SV40 VPs/Tag mimotopes as antigens were set up to investigate the presence in healthy subjects of serum IgG/IgM antibodies reacting to SV40 VPs/Tag (191, 192). Immunological data showed that healthy blood donors carry IgG antibodies reacting to SV40 VPs and Tag with a prevalence of 18 and 20\%, respectively $(191,192)$. Furthermore, immunological data from children may suggest that SV40 infection/seroconversion occurs early in life, i.e., at 6 months of age $(190,193)$.

Antibodies against SV40 VPs in sera from multiple transfused patients affected by thalassemia major had a higher prevalence than healthy subjects of the same age (31 years old, both cohorts). These data indicate that this PyV could have been transmitted by blood transfusions, along with other natural sources (209). Furthermore, the increased prevalence of SV40 antibodies was 
significantly higher in the older age group of patients (41-50 years old) than in age-matched controls (38 vs. $20 \%$ ).

In a recent investigation, SV40 neutralizing antibodies with a prevalence in the range of 7 and $18 \%$ were revealed in sera from women in Huston, Texas, employing a plaque reduction SV40-neutralization assay. The authors identified ethnicity as a significant factor associated with high seroprevalence SV40 neutralizing antibodies reported in Hispanic groups, including subjects from Houston (210). It is worth recalling that SV40contaminated live polio vaccines, as candidate vaccines, were tested during large field trials in some Latin American Countries, due to their potential for being naïve vaccines.

Overall, immunological data indicate that SV40 is circulating in humans inducing IgM, IgG including neutralizing antibodies, which can be detected in sera with a mean prevalence of $\sim 20 \%$ in healthy individuals. Recent immunological data, despite being obtained with specific SV40 mimotopes, do not rule out the hypothesis that another polyomavirus, still unknown, closely related to SV40 is circulating in humans.

\section{ASSOCIATION OF SV40 WITH HUMAN TUMORS}

The hypothesis that SV40 might be associated to human malignancies has been investigated with a large number of molecular, immunological, and epidemiological studies (Table 2). This oncogenic PyV was previously associated with a broad range of tumor types including, malignant pleural mesothelioma (MPM) (80, 81, 227-233, 235, 238, 240-243, $256-258)$, bone $(98,215,224)$, brain $(212-214,217,219-$ $221,259,260)$, lung $(227,234)$, thyroid $(82,244)$, pituitary (179), and urothelial (245) tumors, pleomorphic adenomas of parotid glands (83), choroid plexus tumors, and ependymomas in children (160). In addition, footprints from SV40 DNA have been detected in breast (84) and colon cancer specimens (222). Interestingly, DNA sequences belonging to SV40 have also been found in an AIDS patient with a cerebral lesion (216). More recently, a study conducted with an innovative analysis, known as RNA sequencing (RNA-seq), identified SV40 mRNAs, in tumor samples from low-grade glioma affected patients (219). Different lympho-proliferative disorders (85, $239,254,255)$, including non-Hodgkin's lymphoma (79, 247 251, 260) have also been associated with SV40 infection. It has been reported that the homologous and autologous implantation of SV40-transformed cells in humans caused the growth of nodules, thus suggesting that this $\mathrm{PyV}$ presents oncogenic capacity in humans (261). These studies support an association of human cancers with SV40. These results, obtained mainly by PCR, Southern blot hybridization, DNA sequencing, and immunohistochemistry (IHC) were confirmed by a multi-institutional study (80), but confuted by another group of investigators (262). Among SV40-positive tumor types, MPM has been detected as SV40-positive in many investigations (80, 81, 227-233, 235, 238, 240-243, 256-258, 263), while the mechanisms of SV40 oncogenesis have also been studied $(9,44,258,264,265)$. Interestingly, when normal HMC were exposed to both SV40 and asbestos fibers, the transformation rate increased significantly compared to the controls (9). High exposition to asbestos fibers alone can cause progressive fibrosis (i.e., asbestosis) and in the worse cases, lung cancer (266) and MPM (9). Many studies reported the synergistic activities of SV40 and asbestos on MPM development in geographical areas with high levels of asbestos exposure and SV40-contaminated polio vaccines $(9,81,187,232,236,239)$. High prevalence of SV40 DNA sequences in MPM tissues reflects that relation to SV40-contaminated polio vaccines $(9,81,187,232,236,239)$. The majority of human cancers mentioned above correspond to tumors, which develop in rodents inoculated with SV40 and in SV40-transgenic mice.

It appears that in the same kind of tumor, prevalence of SV40 sequences differs in distinct geographical areas. For example, it has been reported that in the U.S. and Europe 20-83\% of MPM tested SV40-positive (80, 228, 230, 235, 236, 249), while sequences of this PyV in MPM from Turkey and Austria have never been detected $(235,267)$, or detected with low frequency, as in Sweden (228). Similarly, the prevalence SV40 DNA detected in bone tumors is different for example in Hungary (74\%) and Germany (24\%) (226). In addition, SV40-positive MPMs were found in two different studies in Japan with a prevalence ranging between 6 and 44\% (241, 268), whereas another investigation conducted in a cohort of Vietnamese MPM patients detected 20\% SV40-positive tumors (81).

The association between SV40 and human tumors is based on results obtained by many investigators $(80,98,213,218$, $220,225,227,230,234,255,256)$. Most of these studies detected SV40 DNA sequences, using qualitative PCR techniques, in tumor specimens. However, these assays do not provide the quantification of SV40 DNA as a copy number, nor investigated the physical state of the viral DNA, i.e., integrated and/or episomal $(96,98)$. In other studies SV40 mRNA and/or Tag/tag oncoproteins were analyzed in tumors $(9,68$, $81,83,160,219)$, or quantified the amount of SV40 DNA sequences via $\mathrm{qPCR}$ methods $(240,268,269)$. The majority of these qualitative/quantitative assays (Table 2) were carried out targeting different SV40 Tag sequences. Together with these sequences, other SV40 regions were PCR analyzed, including the control region and late gene sequences $(181,220)$. These data indicate that SV40 DNA regions detected in human tumors were not due to PCR contaminations with recombinant plasmids carrying SV40 Tag sequences. In addition, in studies based on IHC staining, the localization of the SV40 Tag in the SV40infected cell is shown (79-85). Studies carried out on SV40 Tag-positive cells demonstrated that the cell transformation is related to the activation of specific autocrine/paracrine loops. In this context, different growth factors and their receptors were analyzed, such as HGF and its receptor (HGFR or Met) (44), the vascular endothelial growth factor (VEGF) and its receptor (VEGFR) $(270,271)$ as well as (IGF-1) and its receptor, in T-antigen-mediated growth $(272,273)$. Concordant data were reported on the ability of the SV40 Tag to induce growth factor receptor/growth factor loops, which in turn stimulates cellcycle progression into the $\mathrm{S}$ phase. These results suggest that 
TABLE 2 | SV40-positive human tumors.

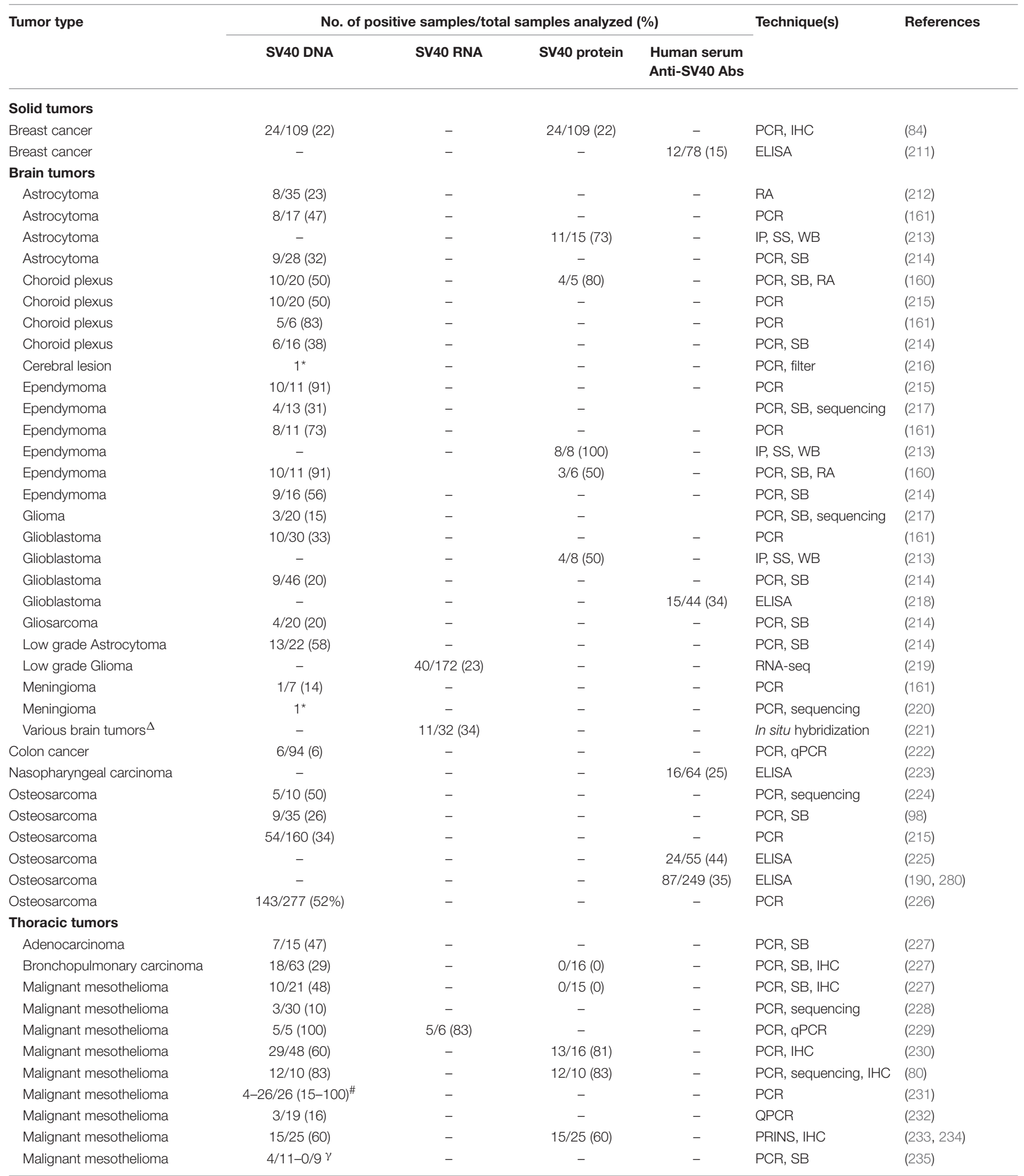


TABLE 2 | Continued

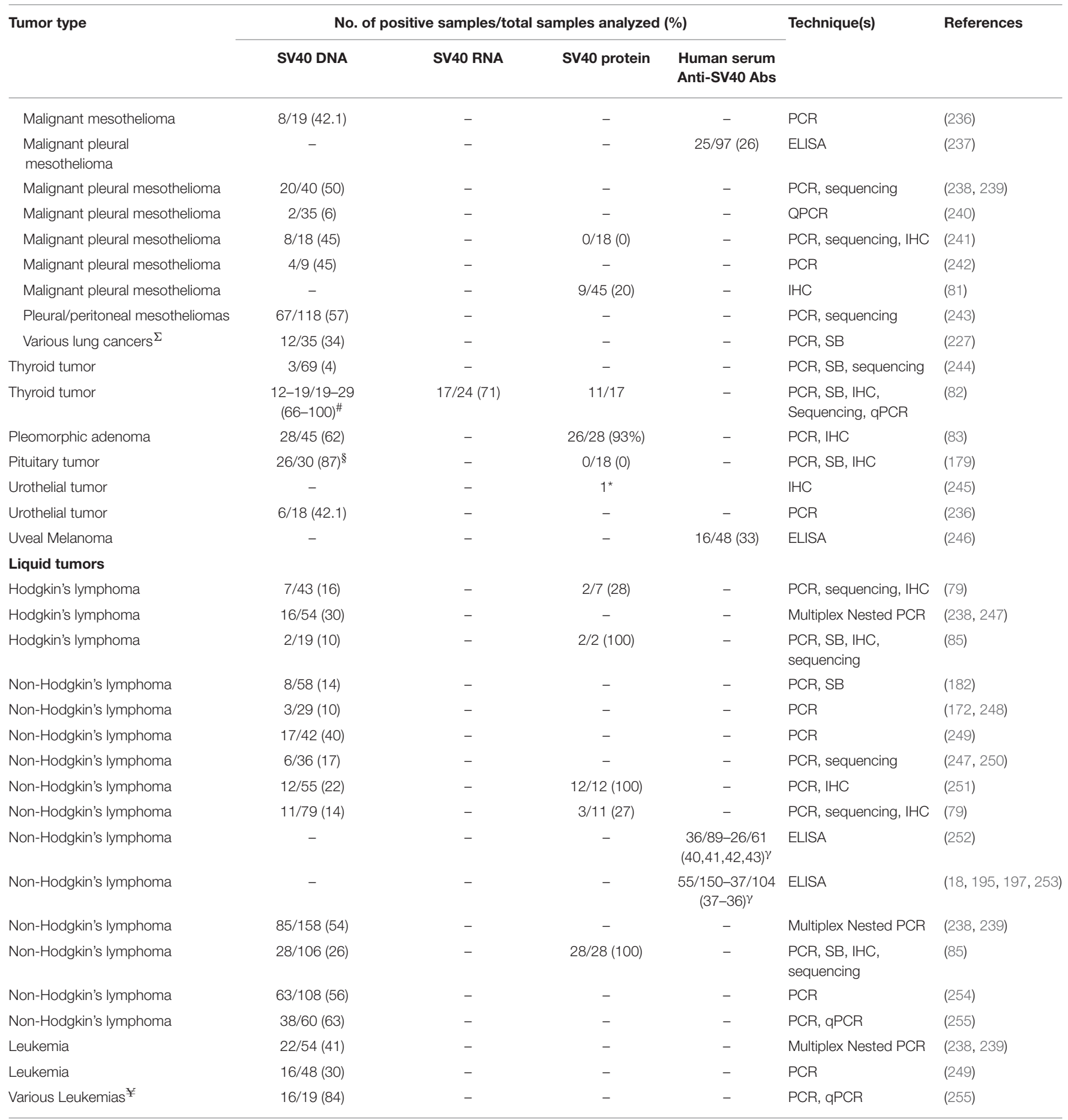

${ }^{*}$ Case reports; ${ }^{\triangle}$ Angiofibroma, astrocytoma, metastatic brain tumors, meningiomas, neurinomas, oligodendrogliomas; ${ }^{\#} D i f f e r e n t$ primer set; ${ }^{\top}$ Two different cohorts; ${ }^{\Sigma}$ Pleomorphic carcinoma, Neuroendocrine carcinoma, Squamous cell carcinoma, others not specified ${ }^{\S}$ Polyomaviral primers that hybridized to SV4O and BKPyV internal probes; ${ }^{\sharp} B c e l l$ acute Iymphoblastic leukemia, B-cell precursor acute lymphoblastic leukemia, T-cell acute lymphoblastic leukemia. IP, Immunoprecipitation; SS, Silver staining; WB, Western blot; PCR, Polymerase chain reaction; PRINS, Primed in situ assay (DNA detection); GPCR, real time quantitative PCR; IHC, Immunohistochemistry; RA, restriction analysis.

a few cells, found to be SV40-positive, induce SV40-negative cells on the microenvironment toward the transformation. The SV40-infected cells have also been determined by several in vitro studies $(56,58-65)$. Different hypotheses have been formulated on the mechanisms of SV40 carcinogenesis in human, including the "hit and run mechanism" which has been investigated in transgenic mice (274). However, this hypothesis cannot be proven in humans. Most of the reports mentioned above are 
related to association studies in which the causative role of SV40 in inducing human tumors cannot be proven. It is plausible that this $\mathrm{PyV}$ may act as a co-factor during the tumorigenic process, either during the early phase of oncogenesis or in the late phase of tumor progression. Indeed, as for other viruses (17), in normal physiological conditions, the immune system counteracts the oncogenic potential of SV40 (194) whose infection could be acquired early in life (190, 193). However, in certain host conditions, such as in immunocompromised individuals, SV40 may exert its oncogenic activities. It is also possible that SV40 acts in a late phase when the cell is already transformed. In these pre-neoplastic cells SV40 Tag/tag expression could favor full transformation. Further studies may clarify this important aspect.

Some studies have reported negative data on an association between human tumors and SV40 (235, 263, 274-277). These investigations have shown neither viral DNA (or SV40 DNA at low prevalence) nor viral oncoproteins and miRNAs in the same tumor types found to be SV40-positive in other studies $(240,248,275-278)$. This is an important issue that has fueled the controversy about SV40 in humans and in human tumors (262). It is important to point out, however, that a SV40 prevalence of about 5\% was shown in those studies, even if it was considered statistically no-significant in considering SV40 a risk factor for human cancers (9, 240, 262). Another relevant issue was highlighted by Lopez-Rios et al. who evidenced the risk of false-positive PCR results accountable by plasmids carrying SV40 sequences circulating in common laboratories, thereby creating overly-high positive rates (262). Negative results have also been published in another independent report from Aaronson and colleagues, reaching similar conclusions (279). Indeed, this study shows no evidence for Tag antigen expression in a series of MPM tumors and derived cell lines (279). For this reason, over time, molecular techniques/protocols have been used ever-more carefully in order to prevent false-positive results, while still revealing any case evidence of SV40 infection in humans and human cancers $(270,276)$. The different assays employed to isolate DNA from tumor tissues affecting the results is also considered as an explanation for this discrepancy (79). Indeed, several commercial kits prevent the isolation of SV40 DNA that is lower than $5.2 \mathrm{~kb}$ in length, i.e., too small. Furthermore, SV40 DNA can be amplified with certain sets of primers but not with others $(160,230)$. In summary, further studies with new approaches are needed to clarify these conflicting results and to address the role of SV40 in human cancers.

To better elucidate these controversies, novel indirect ELISA tests employing synthetic peptides as mimotopes/specific SV40 antigens were set up (191, 192). These immunological and specific assays established that anti-SV40 antibodies can be revealed in human sera from patients affected by different tumors $(211,218,223,225,237,246,252,253,280,281)$, of the same kind found to be SV40-positive by molecular biology techniques. A significantly higher SV40 antibody prevalence was detected in sera from MPM, glioblastoma multiforme, osteosarcoma, and non-Hodgkin's lymphoma patients compared to age-/gender-matched healthy subjects $(218,225,237,252,253,280)$.

\section{ASSOCIATION OF SV40 WITH HUMAN NON-MALIGNANT DISEASES}

Many reports have suggested that the kidney could be the main site for SV40 latency in humans as it occurs in monkeys, that are the natural animal host $(1,189)$. For this reason, an association between SV40 infection and kidney-related diseases was investigated. DNA sequences from this PyV were found in renal tubular epithelial cells nuclei, PBMCs and renal biopsies derived from patients affected by focal segmental glomerulosclerosis, thus suggesting the possible involvement of SV40 in kidney diseases (184). This assumption has been further strengthened through the isolation of SV40 virions in co-cultured urine sediment cells from a nephropathy-affected patient with CV-1 cells, which are SV40 permissive cells derived from monkeys (183). Furthermore, molecular evidence that SV40/BKPyV co-infection occurs in patients with post-transplantation interstitial nephritis has also been reported, suggesting that SV40 may contribute to this disease after the renal transplant in cooperation with $\mathrm{BKPyV}$ (183). Other studies indicate that SV40 seems to be associated with neurological diseases, including multiple sclerosis (281283). DNA sequences from SV40 have also been detected in allografts from immunocompromised pediatric renal transplant recipients and in the kidneys of young adult lung-transplant patients $(162,284)$. Therefore, it is reasonable to propose that a weak immune system, typical of transplant recipients subjected to iatrogenic immunosuppression, could be a risk factor for SV40 infection, as for other PyVs (17).

\section{CONCLUSIONS}

SV40 infection in different human populations worldwide has been reported by many groups (160-164). Indeed, SV40 DNA sequences were detected in normal tissues, such as PBMCs (161, 182, 187), leukocytes from organ and blood donors (180, 181), and pituitary tissues (179). Specific immunological assays identified IgG and IgM antibodies against SV40 VPs and Tag in sera from normal children, adults and elderly subjects (190, 191, 193, 194). In addition, SV40 neutralizing antibodies were detected, in different investigations, using the plaque reduction assay, which is a high specific test demonstrating that the SV40 infection occurred in subjects/patients (203, 210, 285). These data cumulatively indicate that SV40, or a closely related polyomavirus, is circulating in humans. Conflicting results have been published on the association between different human tumors and SV40. Although this oncogenic PyV was previously associated with a broad range of tumor types including brain $(213,220,234)$ and bone tumors (98), MPMs $(80,81,227,230)$, and different lymphoproliferative disorders $(85,239,249,254)$, other investigators reported negative results when analyzing the same tumor types $(238,275-279)$. In addition, these studies are mainly based on the detection of viral DNA. Other works carried out in tumor specimens investigated, to a lesser extent, 
the viral DNA status (integrated or/and episomal), mRNA, and the expression of viral oncoproteins $(84,98,213,219)$. Immunological studies detected specific antibodies against SV40 in sera from tumor affected patients $(218,225,237,252,280)$.

The existence of an SV40-like human polyomavirus, which is still unknown, cannot be ruled out. Recently, a new lymphotropic polyomavirus (HPyV9) was identified in humans (286). It turned out that HPyV9 has great homology with the monkey LPyV, which has been known since the 1960s (287).

The role of SV40 in human tumors, if any, remains to be proven. This is an important issue and certainly deserves further attention with detailed and innovative investigations.

\section{REFERENCES}

1. Sweet BH, Hilleman MR. The vacuolating virus, S.V. 40. Proc Soc Exp Biol Med. (1960) 105:420-7. doi: 10.3181/00379727-105-26128

2. Polyomaviridae Study Group of the International Committee on Taxonomy of Viruses, Calvignac-Spencer S, Feltkamp MCW, Daugherty MD, Moens U, Ramqvist T, et al. A taxonomy update for the family Polyomaviridae. Arch Virol. (2016) 161:1739-50. doi: 10.1007/s00705-016-2794-y

3. Khalili K, Sariyer IK, Safak M. Small tumor antigen of polyomaviruses: role in viral life cycle and cell transformation. J Cell Physiol. (2008) 215:309-19. doi: $10.1002 /$ jcp. 21326

4. O'Neill FJ, Carroll D. Amplification of papovavirus defectives during serial low multiplicity infections. Virology. (1981) 112:800-3. doi: 10.1016/0042-6822(81)90330-5

5. Diamandopoulos GT. Leukemia, lymphoma, and osteosarcoma induced in the Syrian golden hamster by simian virus 40. Science. (1972) 176:173-5. doi: $10.1126 /$ science.176.4031.173

6. Coe JE, Green I. B-cell origin of hamster lymphoid tumors induced by simian virus 40. J Natl Cancer Inst. (1975) 54:269-70. doi: 10.1093/jnci/54.1.269

7. Cicala C, Avantaggiati ML, Graessmann A, Rundell K, Levine AS, Carbone M. Simian virus 40 small-t antigen stimulates viral DNA replication in permissive monkey cells. J Virol. (1994) 68:3138-44.

8. Nakanishi A, Itoh N, Li PP, Handa H, Liddington RC, Kasamatsu H. Minor capsid proteins of simian virus 40 are dispensable for nucleocapsid assembly and cell entry but are required for nuclear entry of the viral genome. $J$ Virol. (2007) 81:3778-85. doi: 10.1128/JVI.02664-06

9. Qi F, Carbone M, Yang H, Gaudino G. Simian virus 40 transformation, malignant mesothelioma and brain tumors. Expert Rev Respir Med. (2011) 5:683-97. doi: 10.1586/ers.11.51

10. Rotondo JC, Candian T, Selvatici R, Mazzoni E, Bonaccorsi G, Greco $\mathrm{P}$, et al. Tracing males from different continents by genotyping JC polyomavirus in DNA from semen samples. J Cell Physiol. (2017) 232:982-5. doi: $10.1002 /$ jcp. 25686

11. Frisque RJ, Bream GL, Cannella MT. Human polyomavirus JC virus genome. J Virol. (1984) 51:458-69.

12. Tagliapietra A, Rotondo JC, Bononi I, Mazzoni E, Magagnoli F, Maritati $\mathrm{M}$, et al. Footprints of BK and JC Polyomavirus in specimens from females affected by spontaneous abortion. Hum Reprod. (2018) 34:433-40. doi: 10.1093/humrep/dey375

13. Yang $\mathrm{RC}, \mathrm{Wu}$ R. BK virus DNA: complete nucleotide sequence of a human tumor virus. Science. (1979) 206:456-62. doi: 10.1126/science.2 28391

14. Schowalter RM, Pastrana DV, Pumphrey KA, Moyer AL, Buck CB. Merkel cell polyomavirus and two previously unknown polyomaviruses are chronically shed from human skin. Cell Host Microbe. (2010) 7:509-15. doi: 10.1016/j.chom.2010.05.006

15. Siebrasse EA, Reyes A, Lim ES, Zhao G, Mkakosya RS, Manary MJ, et al. Identification of MW polyomavirus, a novel polyomavirus in human stool. $J$ Virol. (2012) 86:10321-6. doi: 10.1128/JVI.01210-12

\section{AUTHOR CONTRIBUTIONS}

JR: data collection from the literature, writing, and figure preparation. EM and IB: data collection from the literature and figure preparation. MT and FM: manuscript revision.

\section{FUNDING}

This work is supported by funds from the Associazione Italiana per la Ricerca sul Cancro (AIRC) to MT (ID:21617) and to JR (ID:21956). JR is also supported by a postdoctoral fellowship from the Fondazione Umberto Veronesi, Milan, Italy (2019-2020).

16. Lim ES, Reyes A, Antonio M, Saha D, Ikumapayi UN, Adeyemi M, et al. Discovery of STL polyomavirus, a polyomavirus of ancestral recombinant origin that encodes a unique $\mathrm{T}$ antigen by alternative splicing. Virology. (2013) 436:295-303. doi: 10.1016/j.virol.2012.12.005

17. Rotondo JC, Bononi I, Puozzo A, Govoni M, Foschi V, Lanza G, et al. Merkel cell carcinomas arising in autoimmune disease affected patients treated with biologic drugs, including anti-TNF. Clin Cancer Res. (2017) 23:3929-34. doi: 10.1158/1078-0432.CCR-16-2899

18. Mazzoni E, Rotondo JC, Marracino L, Selvatici R, Bononi I, Torreggiani E, et al. Detection of merkel cell polyomavirus DNA in serum samples of healthy blood donors. Front Oncol. (2017) 7:294. doi: 10.3389/fonc.2017.00294

19. Feng H, Shuda M, Chang Y, Moore PS. Clonal integration of a polyomavirus in human Merkel cell carcinoma. Science. (2008) 319:1096100. doi: $10.1126 /$ science. 1152586

20. Comerford SA, Schultz N, Hinnant EA, Klapproth S, Hammer RE. Comparative analysis of SV40 17kT and LT function in vivo demonstrates that LT's C-terminus re-programs hepatic gene expression and is necessary for tumorigenesis in the liver. Oncogenesis. (2012) 1:e28. doi: 10.1038 /oncsis.2012.27

21. Khalili K, Brady J, Khoury G. Translational regulation of SV40 early mRNA defines a new viral protein. Cell. (1987) 48:639-45. doi: 10.1016/0092-8674(87)90242-X

22. Griffith JP, Griffith DL, Rayment I, Murakami WT, Caspar DL. Inside polyomavirus at 25-A resolution. Nature. (1992) 355:652-4. doi: 10.1038/355652a0

23. Kawano M, Doi K, Fukuda H, Kita Y, Imai K, Inoue T, et al. SV40 VP1 major capsid protein in its self-assembled form allows VP1 pentamers to coat various types of artificial beads in vitro regardless of their sizes and shapes. Biotechnol Rep. (2015) 5:105-11. doi: 10.1016/j.btre.2014.12.008

24. Daniels R, Sadowicz D, Hebert DN. A very late viral protein triggers the lytic release of SV40. PLoS Pathog. (2007) 3:e98. doi: 10.1371/journal.ppat.0030098

25. Henriksen S, Hansen T, Bruun J-A, Rinaldo $\mathrm{CH}$. The presumed polyomavirus viroporin VP4 of simian virus 40 or human BK polyomavirus is not required for viral progeny release. J Virol. (2016) 90:10398-413. doi: 10.1128/JVI.01326-16

26. Saribas AS, Coric P, Bouaziz S, Safak M. Expression of novel proteins by polyomaviruses and recent advances in the structural and functional features of agnoprotein of JC virus, BK virus, and simian virus 40. J Cell Physiol. (2018) 234:8295-315. doi: 10.1002/jcp.27715

27. Sullivan CS, Grundhoff AT, Tevethia S, Pipas JM, Ganem D. SV40-encoded microRNAs regulate viral gene expression and reduce susceptibility to cytotoxic T cells. Nature. (2005) 435:682-6. doi: 10.1038/nature03576

28. Campanero-Rhodes MA, Smith A, Chai W, Sonnino S, Mauri L, Childs RA, et al. N-glycolyl GM1 ganglioside as a receptor for simian virus 40. J Virol. (2007) 81:12846-58. doi: 10.1128/JVI.01311-07

29. Atwood WJ, Norkin LC. Class I major histocompatibility proteins as cell surface receptors for simian virus 40. J Virol. (1989) 63:4474-7. 
30. Anderson HA, Chen Y, Norkin LC. Bound simian virus 40 translocates to caveolin-enriched membrane domains, and its entry is inhibited by drugs that selectively disrupt caveolae. Mol Biol Cell. (1996) 7:1825-34. doi: $10.1091 / \mathrm{mbc} .7 .11 .1825$

31. Luo Y, Motamedi N, Magaldi TG, Gee GV, Atwood WJ, DiMaio D. Interaction between simian virus 40 major capsid protein VP1 and cell surface ganglioside GM1 triggers vacuole formation. MBio. (2016) 7:e00297. doi: $10.1128 / \mathrm{mBio} .00297-16$

32. Pelkmans L, Kartenbeck J, Helenius A. Caveolar endocytosis of simian virus 40 reveals a new two-step vesicular-transport pathway to the ER. Nat Cell Biol. (2001) 3:473-83. doi: 10.1038/35074539

33. Engel S, Heger T, Mancini R, Herzog F, Kartenbeck J, Hayer A, et al. Role of endosomes in simian virus 40 entry and infection. J Virol. (2011) 85:4198-211. doi: 10.1128/JVI.02179-10

34. Nakanishi A, Shum D, Morioka H, Otsuka E, Kasamatsu H. Interaction of the Vp3 nuclear localization signal with the importin alpha 2/beta heterodimer directs nuclear entry of infecting simian virus 40. J Virol. (2002) 76:9368-77. doi: 10.1128/JVI.76.18.9368-9377.2002

35. Nakanishi A, Clever J, Yamada M, Li PP, Kasamatsu H. Association with capsid proteins promotes nuclear targeting of simian virus 40 DNA. Proc Natl Acad Sci USA. (1996) 93:96-100. doi: 10.1073/pnas.93.1.96

36. Schmidt K, Keiser S, Günther V, Georgiev O, Hirsch HH, Schaffner W, et al. Transcription enhancers as major determinants of SV40 polyomavirus growth efficiency and host cell tropism. J Gen Virol. (2016) 97:1597-603. doi: 10.1099/jgv.0.000487

37. DeCaprio JA, Garcea RL. A cornucopia of human polyomaviruses. Nat Rev Microbiol. (2013) 11:264-76. doi: 10.1038/nrmicro2992

38. Gazdar AF, Butel JS, Carbone M. SV40 and human tumours: myth, association or causality? Nat Rev Cancer. (2002) 2:957-64. doi: $10.1038 / \operatorname{nrc} 947$

39. Wiley SR, Kraus RJ, Zuo F, Murray EE, Loritz K, Mertz JE. SV40 early-tolate switch involves titration of cellular transcriptional repressors. Genes Dev. (1993) 7:2206-19. doi: 10.1101/gad.7.11.2206

40. Dornreiter I, Höss A, Arthur AK, Fanning E. SV40 T antigen binds directly to the large subunit of purified DNA polymerase alpha. EMBO J. (1990) 9:3329-36. doi: 10.1002/j.1460-2075.1990.tb07533.x

41. Melendy T, Stillman B. An interaction between replication protein A and SV40 T antigen appears essential for primosome assembly during SV40 DNA replication. J Biol Chem. (1993) 268:3389-95.

42. An P, Sáenz Robles MT, Pipas JM. Large T antigens of polyomaviruses: amazing molecular machines. Annu Rev Microbiol. (2012) 66:213-36. doi: 10.1146/annurev-micro-092611-150154

43. Barbanti-Brodano G, Sabbioni S, Martini F, Negrini M, Corallini A, Tognon M. Simian virus 40 infection in humans and association with human diseases: results and hypotheses. Virology. (2004) 318:1-9. doi: 10.1016/j.virol.2003.09.004

44. Cacciotti P, Libener R, Betta P, Martini F, Porta C, Procopio A, et al. SV40 replication in human mesothelial cells induces $\mathrm{HGF} / \mathrm{Met}$ receptor activation: a model for viral-related carcinogenesis of human malignant mesothelioma. Proc Natl Acad Sci USA. (2001) 98:12032-7. doi: 10.1073/pnas.211026798

45. Bocchetta M, Eliasz S, De Marco MA, Rudzinski J, Zhang L, Carbone M. The SV40 large T antigen-p53 complexes bind and activate the insulinlike growth factor-I promoter stimulating cell growth. Cancer Res. (2008) 68:1022-9. doi: 10.1158/0008-5472.CAN-07-5203

46. Bocchetta M, Miele L, Pass HI, Carbone M. Notch-1 induction, a novel activity of SV40 required for growth of SV40-transformed human mesothelial cells. Oncogene. (2003) 22:81-9. doi: 10.1038/sj.onc.1 206097

47. Chen H, Campisi J, Padmanabhan R. SV40 large T antigen transactivates the human $\mathrm{cdc} 2$ promoter by inducing a CCAAT box binding factor. J Biol Chem. (1996) 271:13959-67. doi: 10.1074/jbc.271.24.13959

48. Foster DA, Yellen P, Xu L, Saqcena M. Regulation of G1 cell cycle progression: distinguishing the restriction point from a nutrientsensing cell growth checkpoint(s). Genes Cancer. (2010) 1:1124-31. doi: $10.1177 / 1947601910392989$

49. Bikel I, Loeken MR. Involvement of simian virus 40 (SV40) small t antigen in trans activation of SV40 early and late promoters. J Virol. (1992) 66:1489-94.
50. Porrás A, Gaillard S, Rundell K. The simian virus 40 small-t and large$\mathrm{T}$ antigens jointly regulate cell cycle reentry in human fibroblasts. J Virol. (1999) 73:3102-7.

51. Gruda MC, Zabolotny JM, Xiao JH, Davidson I, Alwine JC. Transcriptional activation by simian virus 40 large $\mathrm{T}$ antigen: interactions with multiple components of the transcription complex. Mol Cell Biol. (1993) 13:961-9. doi: 10.1128/MCB.13.2.961

52. Good PJ, Welch RC, Barkan A, Somasekhar MB, Mertz JE. Both VP2 and VP3 are synthesized from each of the alternative spliced late 19S RNA species of simian virus 40. J Virol. (1988) 62:944-53.

53. Okubo E, Lehman JM, Friedrich TD. Negative regulation of mitotic promoting factor by the checkpoint kinase chk1 in simian virus 40 lytic infection. J Virol. (2003) 77:1257-67. doi: 10.1128/JVI.77.2.1257-1267.2003

54. Gordon-Shaag A, Ben-Nun-Shaul O, Roitman V, Yosef Y, Oppenheim A. Cellular transcription factor $\mathrm{Spl}$ recruits simian virus 40 capsid proteins to the viral packaging signal, ses. J Virol. (2002) 76:5915-24. doi: 10.1128/JVI.76.12.5915-5924.2002

55. Clayson ET, Brando LV, Compans RW. Release of simian virus 40 virions from epithelial cells is polarized and occurs without cell lysis. J Virol. (1989) 63:2278-88.

56. Bocchetta M, Di Resta I, Powers A, Fresco R, Tosolini A, Testa JR, et al. Human mesothelial cells are unusually susceptible to simian virus 40 mediated transformation and asbestos cocarcinogenicity. Proc Natl Acad Sci USA. (2000) 97:10214-9. doi: 10.1073/pnas.170207097

57. O'Neill FJ, Xu XL, Miller TH. Host range determinant in the late region of SV40 and RF virus affecting growth in human cells. Intervirology. (1990) 31:175-87. doi: 10.1159/000150152

58. Katzman RB, Seeger M, Rundell K. SV40 reporter viruses. J Virol Methods. (2008) 150:7-13. doi: 10.1016/j.jviromet.2008.02.013

59. Atkin SJL, Griffin BE, Dilworth SM. Polyoma virus and simian virus 40 as cancer models: history and perspectives. Semin Cancer Biol. (2009) 19:211-7. doi: 10.1016/j.semcancer.2009.03.001

60. Small MB, Gluzman Y, Ozer HL. Enhanced transformation of human fibroblasts by origin-defective simian virus 40. Nature. (1982) 296:671-2. doi: 10.1038/296671a0

61. Gluzman Y. SV40-transformed simian cells support the replication of early SV40 mutants. Cell. (1981) 23:175-82. doi: 10.1016/0092-8674(81)90282-8

62. Hirai K, Lehman J, Defendi V. Integration of simian virus 40 deoxyribonucleic acid into the deoxyribonucleic acid of primary infected Chinese hamster cells. J Virol. (1971) 8:708-15.

63. Suárez HG, Morris AG, Lavialle C, Cassingena R. Enhanced SV 40-virus replication in Chinese hamster kidney cells pretreated with 5-iodo-2'deoxyuridine. Arch Virol. (1976) 50:249-53. doi: 10.1007/BF01320580

64. Morelli C, Barbisan F, Iaccheri L, Tognon M. SV40-immortalized human fibroblasts as a source of SV40 infectious virions. Mol Med. (2004) 10:112-6. doi: 10.2119/2004-00037

65. Morelli C, Barbisan F, Iaccheri L, Tognon M. Simian virus 40 persistent infection in long-term immortalized human fibroblast cell lines. J Neurovirol. (2004) 10:250-4. doi: 10.1080/13550280490441185

66. Martini F, Corallini A, Balatti V, Sabbioni S, Pancaldi C, Tognon M. Simian virus 40 in humans. Infect Agents Cancer. (2007) 2:13. doi: $10.1186 / 1750-9378-2-13$

67. Mazzoni E, Rigolin GM, Alaribe FN, Pancaldi C, Maniero S, Comar M, et al. Simian virus 40 efficiently infects human $\mathrm{T}$ lymphocytes and extends their lifespan. Exp Hematol. (2012) 40:466-76. doi: 10.1016/j.exphem.2012.02.008

68. Dolcetti R, Martini F, Quaia M, Gloghini A, Vignocchi B, Cariati R, et al. Simian virus 40 sequences in human lymphoblastoid B-cell lines. J Virol. (2003) 77:1595-7. doi: 10.1128/JVI.77.2.1595-1597.2003

69. O’Neill FJ, Carney H, Hu Y. Host range analysis of simian virus 40, BK virus and chimaeric SV40/BKV: relative expression of large T-antigen and Vp1 in infected and transformed cells. Dev Biol Stand. (1998) 94:191-205.

70. Lewis ED, Manley JL. Repression of simian virus 40 early transcription by viral DNA replication in human 293 cells. Nature. (1985) 317:172-5. doi: $10.1038 / 317172 \mathrm{a} 0$

71. Lebkowski JS, Clancy S, Calos MP. Simian virus 40 replication in adenovirustransformed human cells antagonizes gene expression. Nature. (1985) 317:169-71. doi: 10.1038/317169a0 
72. Jensen F, Koprowski H, Ponten JA. Rapid transformation of human fibroblast cultures by simian virus. Proc Natl Acad Sci USA. (1963) 50:343-8. doi: $10.1073 /$ pnas. 50.2 .343

73. Shein HM. Transformation of astrocytes and destruction of spongioblasts induced by a simian tumor virus (SV40) in cultures of human fetal neuroglia. J Neuropathol Exp Neurol. (1967) 26:60-76. doi: 10.1097/00005072-196701000-00005

74. Zhang L, Qi F, Gaudino G, Strianese O, Yang H, Morris P, et al. Tissue tropism of SV40 transformation of human cells: role of the viral regulatory region and of cellular oncogenes. Genes Cancer. (2010) 1:1008-20. doi: 10.1177/1947601910395580

75. Rotondo JC, Bosi S, Bassi C, Ferracin M, Lanza G, Gafà R, et al. Gene expression changes in progression of cervical neoplasia revealed by microarray analysis of cervical neoplastic keratinocytes. J Cell Physiol. (2015) 230:806-12. doi: 10.1002/jcp.24808

76. Torreggiani E, Rossini M, Bononi I, Pietrobon S, Mazzoni E, Iaquinta MR, et al. Protocol for the long-term culture of human primary keratinocytes from the normal colorectal mucosa. J Cell Physiol. (2019) 234:9895-905. doi: $10.1002 /$ jcp. 28300

77. Li J, Wang X, Diaz J, Tsang SH, Buck CB, You J. Merkel cell polyomavirus large $\mathrm{T}$ antigen disrupts host genomic integrity and inhibits cellular proliferation. J Virol. (2013) 87:9173-88. doi: 10.1128/JVI.01216-13

78. Cheng J, Rozenblatt-Rosen O, Paulson KG, Nghiem P, DeCaprio JA. Merkel cell polyomavirus large $\mathrm{T}$ antigen has growth-promoting and inhibitory activities. J Virol. (2013) 87:6118-26. doi: 10.1128/JVI.00385-13

79. Martini F, Dolcetti R, Gloghini A, Iaccheri L, Carbone A, Boiocchi $\mathrm{M}$, et al. Simian-virus-40 footprints in human lymphoproliferative disorders of HIV- and HIV+ patients. Int J Cancer. (1998) 78:669-74. doi: 10.1002/(SICI)1097-0215(19981209)78:6<669::AID-IJC1>3.0.CO;2-B

80. Testa JR, Carbone M, Hirvonen A, Khalili K, Krynska B, Linnainmaa K, et al. A multi-institutional study confirms the presence and expression of simian virus 40 in human malignant mesotheliomas. Cancer Res. (1998) 58:4505-9.

81. Thanh TD, Tho NV, Lam NS, Dung NH, Tabata C, Nakano Y. Simian virus 40 may be associated with developing malignant pleural mesothelioma. Oncol Lett. (2016) 11:2051-6. doi: 10.3892/ol.2016.4174

82. Vivaldi A, Pacini F, Martini F, Iaccheri L, Pezzetti F, Elisei R, et al. Simian virus 40-like sequences from early and late regions in human thyroid tumors of different histotypes. J Clin Endocrinol Metab. (2003) 88:892-9. doi: $10.1210 /$ jc.2002-020436

83. Martinelli M, Martini F, Rinaldi E, Caramanico L, Magri E, Grandi E, et al. Simian virus 40 sequences and expression of the viral large $\mathrm{T}$ antigen oncoprotein in human pleomorphic adenomas of parotid glands. Am J Pathol. (2002) 161:1127-33. doi: 10.1016/S0002-9440(10)64389-1

84. Hachana M, Trimeche M, Ziadi S, Amara K, Korbi S. Evidence for a role of the Simian virus 40 in human breast carcinomas. Breast Cancer Res Treat. (2009) 113:43-58. doi: 10.1007/s10549-008-9901-z

85. Meneses A, Lopez-Terrada D, Zanwar P, Killen DE, Monterroso V, Butel JS, et al. Lymphoproliferative disorders in Costa Rica and simian virus 40 . Haematologica. (2005) 90:1635-42.

86. Lane DP, Crawford LV. T antigen is bound to a host protein in SV40transformed cells. Nature. (1979) 278:261-3. doi: 10.1038/278261a0

87. Hartmann T, Xu X, Kronast M, Muehlich S, Meyer K, Zimmermann $\mathrm{W}$, et al. Inhibition of Cullin-RING E3 ubiquitin ligase 7 by simian virus 40 large T antigen. Proc Natl Acad Sci USA. (2014) 111:3371-6. doi: 10.1073/pnas.1401556111

88. Baez CF, Brandão Varella R, Villani S, Delbue S. Human polyomaviruses: the battle of large and small tumor antigens. Virology. (2017) 8:1178122X17744785. doi: 10.1177/1178122X17744785

89. Sáenz Robles MT, Pipas JM. T antigen transgenic mouse models. Semin Cancer Biol. (2009) 19:229-35. doi: 10.1016/j.semcancer.2009.02.002

90. Theile M, Strauss M, Luebbe L, Scherneck S, Krause H, Geissler E. SV40-induced somatic mutations: possible relevance to viral transformation. Cold Spring Harb Symp Quant Biol. (1980) 44(Pt 1):377-82. doi: 10.1101/SQB.1980.044.01.042

91. Stewart N, Bacchetti S. Expression of SV40 large $\mathrm{T}$ antigen, but not small $\mathrm{T}$ antigen, is required for the induction of chromosomal aberrations in transformed human cells. Virology. (1991) 180:49-57. doi: 10.1016/0042-6822(91)90008-Y
92. Ray FA, Peabody DS, Cooper JL, Cram LS, Kraemer PM. SV40T antigen alone drives karyotype instability that precedes neoplastic transformation of human diploid fibroblasts. J Cell Biochem. (1990) 42:13-31. doi: 10.1002/jcb.240420103

93. Ray FA, Meyne J, Kraemer PM. SV40 T antigen induced chromosomal changes reflect a process that is both clastogenic and aneuploidogenic and is ongoing throughout neoplastic progression of human fibroblasts. Mutat Res. (1992) 284:265-73. doi: 10.1016/0027-5107(92)90011-P

94. Williams K, Sobol RW. Mutation research/fundamental and molecular mechanisms of mutagenesis: special issue: DNA repair and genetic instability. Mutat Res. (2013) 743-744:1-3. doi: 10.1016/j.mrfmmm.2013.04.009

95. Boichuk S, Hu L, Hein J, Gjoerup OV. Multiple DNA damage signaling and repair pathways deregulated by simian virus 40 large T antigen. J Virol. (2010) 84:8007-20. doi: 10.1128/JVI.00334-10

96. Shera KA, Shera CA, McDougall JK. Small tumor virus genomes are integrated near nuclear matrix attachment regions in transformed cells. $J$ Virol. (2001) 75:12339-46. doi: 10.1128/JVI.75.24.12339-12346.2001

97. Liu J, Kaur G, Zhawar VK, Zimonjic DB, Popescu NC, Kandpal RP, et al. Role of SV40 integration site at chromosomal interval 1q21.1 in immortalized CRL2504 cells. Cancer Res. (2009) 69:7819-25. doi: 10.1158/0008-5472.CAN-09-1003

98. Mendoza SM, Konishi T, Miller CW. Integration of SV40 in human osteosarcoma DNA. Oncogene. (1998) 17:2457-62. doi: 10.1038/sj.onc.1202179

99. Schüchner S, Wintersberger E. Binding of polyomavirus small $\mathrm{T}$ antigen to protein phosphatase $2 \mathrm{~A}$ is required for elimination of p27 and support of S-phase induction in concert with large T antigen. J Virol. (1999) 73:9266-73.

100. Skoczylas C, Henglein B, Rundell K. PP2A-dependent transactivation of the cyclin A promoter by SV40 ST is mediated by a cell cycle-regulated E2F site. Virology. (2005) 332:596-601. doi: 10.1016/j.virol.2004.12.017

101. Sotillo E, Garriga J, Kurimchak A, Graña X. Cyclin E and SV40 small T antigen cooperate to bypass quiescence and contribute to transformation by activating CDK2 in human fibroblasts. J Biol Chem. (2008) 283:11280-92. doi: 10.1074/jbc.M709055200

102. Frost JA, Alberts AS, Sontag E, Guan K, Mumby MC, Feramisco JR. Simian virus 40 small $\mathrm{t}$ antigen cooperates with mitogen-activated kinases to stimulate AP-1 activity. Mol Cell Biol. (1994) 14:6244-52. doi: 10.1128/MCB.14.9.6244

103. Rotondo JC, Bosi S, Bazzan E, Di Domenico M, De Mattei M, Selvatici R, et al. Methylenetetrahydrofolate reductase gene promoter hypermethylation in semen samples of infertile couples correlates with recurrent spontaneous abortion. Hum Reprod. (2012) 27:3632-8. doi: 10.1093/humrep/ des319

104. Rotondo JC, Selvatici R, Di Domenico M, Marci R, Vesce F, Tognon $\mathrm{M}$, et al. Methylation loss at H19 imprinted gene correlates with methylenetetrahydrofolate reductase gene promoter hypermethylation in semen samples from infertile males. Epigenetics. (2013) 8:990-7. doi: 10.4161/epi.25798

105. Rotondo JC, Borghi A, Selvatici R, Magri E, Bianchini E, Montinari $\mathrm{E}$, et al. Hypermethylation-induced inactivation of the IRF6 gene as a possible early event in progression of vulvar squamous cell carcinoma associated with lichen sclerosus. JAMA Dermatol. (2016) 152:928-33. doi: 10.1001/jamadermatol.2016.1336

106. Rotondo JC, Borghi A, Selvatici R, Mazzoni E, Bononi I, Corazza M, et al. Association of retinoic acid receptor $\beta$ gene with onset and progression of lichen sclerosus-associated vulvar squamous cell carcinoma. JAMA Dermatol. (2018) 154:819-23. doi: 10.1001/jamadermatol.2018.1373

107. Kuss-Duerkop SK, Westrich JA, Pyeon D. DNA tumor virus regulation of host DNA methylation and its implications for immune evasion and oncogenesis. Viruses. (2018) 10:E82. doi: 10.3390/v10020082

108. Jiang Q, Zhang Z, Li S, Wang Z, Ma Y, Hu Y. Defective heat shock factor 1 inhibits the growth of fibrosarcoma derived from simian virus 40/T antigen-transformed MEF cells. Mol Med Rep. (2015) 12:6517-26. doi: $10.3892 / \mathrm{mmr} .2015 .4300$

109. Gupta T, Sáenz Robles MT, Pipas JM. Cellular transformation of mouse embryo fibroblasts in the absence of activator E2Fs. J Virol. (2015) 89:512433. doi: 10.1128/JVI.03578-14 
110. Li N, Yang R, Zhang W, Dorfman H, Rao P, Gorlick R. Genetically transforming human mesenchymal stem cells to sarcomas: changes in cellular phenotype and multilineage differentiation potential. Cancer. (2009) 115:4795-806. doi: 10.1002/cncr.24519

111. Wang Z-Y, Burlak C, Klaunig JE, Kamendulis LM. Development of a cytokine-producing immortalized murine Kupffer cell line. Cytokine. (2014) 70:165-72. doi: 10.1016/j.cyto.2014.07.251

112. Best B, Moran P, Ren B. VEGF/PKD-1 signaling mediates arteriogenic gene expression and angiogenic responses in reversible human microvascular endothelial cells with extended lifespan. Mol Cell Biochem. (2018) 446:199207. doi: 10.1007/s11010-018-3286-Z

113. Shu Y, Yang C, Ji X, Zhang L, Bi Y, Yang K, et al. Reversibly immortalized human umbilical cord-derived mesenchymal stem cells (UC-MSCs) are responsive to BMP9-induced osteogenic and adipogenic differentiation. $J$ Cell Biochem. (2018) 119:8872-86. doi: 10.1002/jcb.27140

114. Gong M, Bi Y, Jiang W, Zhang Y, Chen L, Hou N, et al. Immortalized mesenchymal stem cells: an alternative to primary mesenchymal stem cells in neuronal differentiation and neuroregeneration associated studies. J Biomed Sci. (2011) 18:87. doi: 10.1186/1423-0127-18-87

115. Langert KA, Von Zee CL, Stubbs EB. Tumour necrosis factor $\alpha$ enhances CCL2 and ICAM-1 expression in peripheral nerve microvascular endoneurial endothelial cells. ASN Neuro. (2013) 5:e00104. doi: 10.1042/AN20120048

116. Rundell K, Parakati R. The role of the SV40 ST antigen in cell growth promotion and transformation. Semin Cancer Biol. (2001) 11:5-13. doi: $10.1006 /$ scbi.2000.0341

117. Kitazawa K, Kawasaki S, Shinomiya K, Aoi K, Matsuda A, Funaki T, et al. Establishment of a human corneal epithelial cell line lacking the functional TACSTD2 gene as an in vitro model for gelatinous drop-like dystrophy. Invest Ophthalmol Vis Sci. (2013) 54:5701-11. doi: 10.1167/iovs.1211043

118. Pan X, Wang Y, Yu X, Li J, Zhou N, Du W, et al. Establishment and characterization of an immortalized human hepatic stellate cell line for applications in co-culturing with immortalized human hepatocytes. Int $J$ Med Sci. (2015) 12:248-55. doi: 10.7150/ijms.11002

119. Lee WYW, Zhang T, Lau CPY, Wang CC, Chan K-M, Li G. Immortalized human fetal bone marrow-derived mesenchymal stromal cell expressing suicide gene for anti-tumor therapy in vitro and in vivo. Cytotherapy. (2013) 15:1484-97. doi: 10.1016/j.jcyt.2013.06.010

120. Plaisance-Bonstaff K, Renne R. Viral miRNAs. Methods Mol Biol. (2011) 721:43-66. doi: 10.1007/978-1-61779-037-9_3

121. Sullivan CS, Ganem D. MicroRNAs and viral infection. Mol Cell. (2005) 20:3-7. doi: 10.1016/j.molcel.2005.09.012

122. Bauman Y, Nachmani D, Vitenshtein A, Tsukerman P, Drayman N, Stern-Ginossar N, et al. An identical miRNA of the human JC and BK polyoma viruses targets the stress-induced ligand ULBP3 to escape immune elimination. Cell Host Microbe. (2011) 9:93-102. doi: 10.1016/j.chom.2011.01.008

123. Bauman Y, Drayman N, Ben-Nun-Shaul O, Vitenstein A, Yamin R, Ophir $\mathrm{Y}$, et al. Downregulation of the stress-induced ligand ULBP1 following SV40 infection confers viral evasion from NK cell cytotoxicity. Oncotarget. (2016) 7:15369-81. doi: 10.18632/oncotarget.8085

124. McNees AL, Harrigal LJ, Kelly A, Minard CG, Wong C, Butel JS. Viral microRNA effects on persistent infection of human lymphoid cells by polyomavirus SV40. PLoS ONE. (2018) 13:e0192799. doi: 10.1371/journal.pone.0192799

125. Cicala C, Pompetti F, Carbone M. SV40 induces mesotheliomas in hamsters. Am J Pathol. (1993) 142:1524-33.

126. Van Dyke TA, Finlay C, Miller D, Marks J, Lozano G, Levine AJ. Relationship between simian virus 40 large tumor antigen expression and tumor formation in transgenic mice. J Virol. (1987) 61:2029-32.

127. Wikenheiser KA, Clark JC, Linnoila RI, Stahlman MT, Whitsett JA. Simian virus 40 large $\mathrm{T}$ antigen directed by transcriptional elements of the human surfactant protein $\mathrm{C}$ gene produces pulmonary adenocarcinomas in transgenic mice. Cancer Res. (1992) 52:5342-52.

128. Maroulakou IG, Anver M, Garrett L, Green JE. Prostate and mammary adenocarcinoma in transgenic mice carrying a rat C3(1) simian virus 40 large tumor antigen fusion gene. Proc Natl Acad Sci USA. (1994) 91:11236-40. doi: $10.1073 /$ pnas.91.23.11236

129. Greenberg NM, DeMayo F, Finegold MJ, Medina D, Tilley WD, Aspinall JO, et al. Prostate cancer in a transgenic mouse. Proc Natl Acad Sci USA. (1995) 92:3439-43. doi: 10.1073/pnas.92.8.3439

130. Hurwitz AA, Foster BA, Allison JP, Greenberg NM, Kwon ED. The TRAMP mouse as a model for prostate cancer. Curr Protoc Immunol. (2001) Chapter 20:Unit 20.5. doi: 10.1002/0471142735.im2005s45

131. Santarelli R, Tzeng YJ, Zimmermann C, Guhl E, Graessmann A. SV40 Tantigen induces breast cancer formation with a high efficiency in lactating and virgin WAP-SV-T transgenic animals but with a low efficiency in ovariectomized animals. Oncogene. (1996) 12:495-505.

132. Garabedian EM, Roberts LJ, McNevin MS, Gordon JI. Examining the role of Paneth cells in the small intestine by lineage ablation in transgenic mice. $J$ Biol Chem. (1997) 272:23729-40. doi: 10.1074/jbc.272.38.23729

133. Garabedian EM, Humphrey PA, Gordon JI. A transgenic mouse model of metastatic prostate cancer originating from neuroendocrine cells. Proc Natl Acad Sci USA. (1998) 95:15382-7. doi: 10.1073/pnas.95.26.15382

134. Asamoto M, Hokaiwado N, Cho YM, Takahashi S, Ikeda Y, Imaida K, et al. Prostate carcinomas developing in transgenic rats with SV40 T antigen expression under probasin promoter control are strictly androgen dependent. Cancer Res. (2001) 61:4693-700.

135. Masumori N, Thomas TZ, Chaurand P, Case T, Paul M, Kasper $\mathrm{S}$, et al. A probasin-large $\mathrm{T}$ antigen transgenic mouse line develops prostate adenocarcinoma and neuroendocrine carcinoma with metastatic potential. Cancer Res. (2001) 61:2239-49.

136. Gabril MY, Onita T, Ji PG, Sakai H, Chan FL, Koropatnick J, et al. Prostate targeting: PSP94 gene promoter/enhancer region directed prostate tissuespecific expression in a transgenic mouse prostate cancer model. Gene Ther. (2002) 9:1589-99. doi: 10.1038/sj.gt.3301895

137. Hicks SM, Vassallo JD, Dieter MZ, Lewis CL, Whiteley LO, Fix AS, et al. Immunohistochemical analysis of Clara cell secretory protein expression in a transgenic model of mouse lung carcinogenesis. Toxicology. (2003) 187:217-28. doi: 10.1016/S0300-483X(03)00060-X

138. Garson K, Macdonald E, Dubé M, Bao R, Hamilton TC, Vanderhyden BC. Generation of tumors in transgenic mice expressing the SV40 T antigen under the control of ovarian-specific promoter 1. J Soc Gynecol Investig. (2003) 10:244-50. doi: 10.1016/S1071-55760300073-X

139. Lou D-Q, Molina T, Bennoun M, Porteu A, Briand P, Joulin V, et al. Conditional hepatocarcinogenesis in mice expressing SV 40 early sequences. Cancer Lett. (2005) 229:107-14. doi: 10.1016/j.canlet.2004. 12.032

140. Grippo PJ, Sandgren EP. Highly invasive transitional cell carcinoma of the bladder in a simian virus $40 \mathrm{~T}$-antigen transgenic mouse model. Am J Pathol. (2000) 157:805-13. doi: 10.1016/S0002-9440(10)64594-4

141. Robinson C, van Bruggen I, Segal A, Dunham M, Sherwood A, Koentgen F, et al. A novel SV40 TAg transgenic model of asbestos-induced mesothelioma: malignant transformation is dose dependent. Cancer Res. (2006) 66:1078694. doi: 10.1158/0008-5472.CAN-05-4668

142. Köbbert C, Möllmann C, Schäfers M, Hermann S, Baba HA, Hoffmeier A, et al. Transgenic model of cardiac rhabdomyosarcoma formation. J Thorac Cardiovasc Surg. (2008) 136:1178-86. doi: 10.1016/j.jtcvs.2008.04.022

143. ter Brugge PJ, Ta VBT, de Bruijn MJW, Keijzers G, Maas A, van Gent DC, et al. A mouse model for chronic lymphocytic leukemia based on expression of the SV40 large T antigen. Blood. (2009) 114:119-27. doi: 10.1182/blood-2009-01-198937

144. Stahl S, Sacher T, Bechtold A, Protzer U, Ganss R, Hämmerling GJ, et al. Tumor agonist peptides break tolerance and elicit effective CTL responses in an inducible mouse model of hepatocellular carcinoma. Immunol Lett. (2009) 123:31-7. doi: 10.1016/j.imlet.2009.01.011

145. Iwakura H, Ariyasu H, Li Y, Kanamoto N, Bando M, Yamada G, et al. A mouse model of ghrelinoma exhibited activated growth hormone-insulinlike growth factor I axis and glucose intolerance. Am J Physiol Endocrinol Metab. (2009) 297:E802-811. doi: 10.1152/ajpendo.00205.2009

146. Feigenbaum L, Hinrichs SH, Jay G. JC virus and simian virus 40 enhancers and transforming proteins: role in determining tissue specificity and pathogenicity in transgenic mice. J Virol. (1992) 66:1176-82. 
147. Palmiter RD, Chen HY, Messing A, Brinster RL. SV40 enhancer and large$\mathrm{T}$ antigen are instrumental in development of choroid plexus tumours in transgenic mice. Nature. (1985) 316:457-60. doi: 10.1038/316457a0

148. Brinster RL, Chen HY, Messing A, van Dyke T, Levine AJ, Palmiter RD. Transgenic mice harboring SV40 T-antigen genes develop characteristic brain tumors. Cell. (1984) 37:367-79. doi: 10.1016/0092-8674(84) 90367-2

149. Lee YC, Asa SL, Drucker DJ. Glucagon gene 5'-flanking sequences direct expression of simian virus 40 large $\mathrm{T}$ antigen to the intestine, producing carcinoma of the large bowel in transgenic mice. J Biol Chem. (1992) 267:10705-8.

150. Albert DM, Kumar A, Strugnell SA, Darjatmoko SR, Lokken JM, Lindstrom MJ, et al. Effectiveness of 1alpha-hydroxyvitamin D2 in inhibiting tumor growth in a murine transgenic pigmented ocular tumor model. Arch Ophthalmol. (2004) 122:1365-9. doi: 10.1001/archopht.122. 9.1365

151. Perez-Stable C, Altman NH, Brown J, Harbison M, Cray C, Roos BA. Prostate, adrenocortical, and brown adipose tumors in fetal globin/T antigen transgenic mice. Lab Invest. (1996) 74:363-73.

152. Grabowska MM, DeGraff DJ, Yu X, Jin RJ, Chen Z, Borowsky AD, et al. Mouse models of prostate cancer: picking the best model for the question. Cancer Metastasis Rev. (2014) 33:377-97. doi: 10.1007/s10555-013-9487-8

153. Wenzel AA, O'Hare MN, Shadmand M, Corson TW. Optical coherence tomography enables imaging of tumor initiation in the TAg-RB mouse model of retinoblastoma. Mol Vis. (2015) 21:515-22.

154. Bruns M, Wanger J, Utermöhlen O, Deppert W. An inducible transgenic mouse breast cancer model for the analysis of tumor antigen specific CD8+ T-cell responses. Oncotarget. (2015) 6:38487-503. doi: 10.18632/oncotarget.5750

155. Hirner H, Günes C, Bischof J, Wolff S, Grothey A, Kühl M, et al. Impaired CK1 delta activity attenuates SV40-induced cellular transformation in vitro and mouse mammary carcinogenesis in vivo. PLoS ONE. (2012) 7:e29709. doi: 10.1371/journal.pone.0029709

156. Laviolette LA, Garson K, Macdonald EA, Senterman MK, Courville K, Crane CA, et al. 17beta-estradiol accelerates tumor onset and decreases survival in a transgenic mouse model of ovarian cancer. Endocrinology. (2010) 151:92938. doi: 10.1210/en.2009-0602

157. Chrusciel M, Doroszko M, Stelmaszewska J, Li X, Ziecik AJ, CoelinghBennink HJT, et al. Transgenic mice expressing inhibin $\alpha$-subunit promoter (inh $\alpha$ )/Simian Virus $40 \mathrm{~T}$-antigen (Tag) transgene as a model for the therapy of granulosa cell-derived ovarian cancer. Reprod Biol. (2014) 14:25-31. doi: 10.1016/j.repbio.2013.11.005

158. Braumüller H, Wieder T, Brenner E, Aßmann S, Hahn M, Alkhaled M, et al. T-helper-1-cell cytokines drive cancer into senescence. Nature. (2013) 494:361-5. doi: 10.1038/nature11824

159. Patil PB, Begum S, Joshi M, Kleman MI, Olausson M, SumitranHolgersson S. Phenotypic and in vivo functional characterization of immortalized human fetal liver cells. Scand J Gastroenterol. (2014) 49:70514. doi: 10.3109/00365521.2013.830328

160. Bergsagel DJ, Finegold MJ, Butel JS, Kupsky WJ, Garcea RL. DNA sequences similar to those of simian virus 40 in ependymomas and choroid plexus tumors of childhood. N Engl J Med. (1992) 326:988-93. doi: 10.1056/NEJM199204093261504

161. Martini F, Iaccheri L, Lazzarin L, Carinci P, Corallini A, Gerosa M, et al. SV40 early region and large T antigen in human brain tumors, peripheral blood cells, and sperm fluids from healthy individuals. Cancer Res. (1996) 56:4820-5.

162. Butel JS, Jafar S, Wong C, Arrington AS, Opekun AR, Finegold MJ, et al. Evidence of SV40 infections in hospitalized children. Hum Pathol. (1999) 30:1496-502. doi: 10.1016/S0046-8177(99)90173-9

163. Butel JS, Arrington AS, Wong C, Lednicky JA, Finegold MJ. Molecular evidence of simian virus 40 infections in children. J Infect Dis. (1999) 180:884-7. doi: 10.1086/314915

164. Vanchiere JA, White ZS, Butel JS. Detection of BK virus and simian virus 40 in the urine of healthy children. J Med Virol. (2005) 75:447-54. doi: 10.1002/jmv.20287

165. Horváth LB. Incidence of SV-40 virus neutralizing antibodies in sera of laboratory workers. Acta Microbiol Acad Sci Hung. (1965) 12:201-5.
166. Shah KV, Goverdhan MK, Ozer H. Neutralizing antibodies to SV40 in human sera from South India: search for additional hosts of SV40. Am J Epidemiol. (1971) 93:291-7. doi: 10.1093/oxfordjournals.aje.a121260

167. Carbone M, Rizzo P, Pass HI. Simian virus 40, poliovaccines and human tumors: a review of recent developments. Oncogene. (1997) 15:1877-88. doi: 10.1038/sj.onc.1201375

168. Elswood BF, Stricker RB. Polio vaccines and the origin of AIDS. Med Hypotheses. (1994) 42:347-54. doi: 10.1016/0306-9877(94)90151-1

169. Lapin BA, Chikobava MG. Detection of SV40 in blood samples from healthy subjects in the Russian Federation by RT-PCR. Vestn Akad Med Nauk SSSR. (2009) 2009:7-10.

170. Cutrone R, Lednicky J, Dunn G, Rizzo P, Bocchetta M, Chumakov K, et al. Some oral poliovirus vaccines were contaminated with infectious SV40 after 1961. Cancer Res. (2005) 65:10273-9. doi: 10.1158/0008-5472.CAN-05-2028

171. Sangar D, Pipkin PA, Wood DJ, Minor PD. Examination of poliovirus vaccine preparations for SV40 sequences. Biologicals. (1999) 27:1-10. doi: 10.1006/biol.1998.0170

172. Rizzo P, Di Resta I, Powers A, Ratner H, Carbone M. Unique strains of SV40 in commercial poliovaccines from 1955 not readily identifiable with current testing for SV40 infection. Cancer Res. (1999) 59:6103-8.

173. Melnick JL, Stinebaugh S. Excretion of vacuolating SV-40 virus (papova virus group) after ingestion as a contaminant of oral poliovaccine. Proc Soc Exp Biol Med. (1962) 109:965-8. doi: 10.3181/00379727-10927392

174. Rollison DEM, Page WF, Crawford H, Gridley G, Wacholder S, Martin J, et al. Case-control study of cancer among US Army veterans exposed to simian virus 40-contaminated adenovirus vaccine. Am J Epidemiol. (2004) 160:317-24. doi: 10.1093/aje/kwh212

175. Richmond JE, Parry JV, Gardner SD. Characterisation of a polyomavirus in two foetal rhesus monkey kidney cell lines used for the growth of hepatitis A virus. Arch Virol. (1984) 80:131-46. doi: 10.1007/BF01310654

176. Morris JA, Johnson KM, Aulisio CG, Chanock RM, Knight V. Clinical and serologic responses in volunteers given vacuolating virus (SV40) by respiratory route. Proc Soc Exp Biol Med. (1961) 108:56-9. doi: 10.3181/00379727-108-26843

177. Rotondo JC, Giari L, Guerranti C, Tognon M, Castaldelli G, Fano EA, et al. Environmental doses of perfluorooctanoic acid change the expression of genes in target tissues of common carp. Environ Toxicol Chem. (2018) 37:942-8. doi: 10.1002/etc.4029

178. Trentini A, Manfrinato MC, Castellazzi M, Tamborino C, Roversi G, Volta CA, et al. TIMP-1 resistant matrix metalloproteinase- 9 is the predominant serum active isoform associated with MRI activity in patients with multiple sclerosis. Mult Scler. (2015) 21:1121-30. doi: 10.1177/1352458514560925

179. Woloschak M, Yu A, Post KD. Detection of polyomaviral DNA sequences in normal and adenomatous human pituitary tissues using the polymerase chain reaction. Cancer. (1995) 76:490-6. doi: 10.1002/1097-0142(19950801) 76:3<490::AID-CNCR2820760320>3.0.CO;2-\%23

180. Paracchini V, Garte S, Pedotti P, Poli F, Frison S, Taioli E. Molecular identification of simian virus 40 infection in healthy Italian subjects by birth cohort. Mol Med. (2005) 11:48-51. doi: 10.2119/2005-00007

181. Martini F, Lazzarin L, Iaccheri L, Vignocchi B, Finocchiaro G, Magnani $\mathrm{I}$, et al. Different simian virus 40 genomic regions and sequences homologous with SV40 large T antigen in DNA of human brain and bone tumors and of leukocytes from blood donors. Cancer. (2002) 94:1037-48. doi: $10.1002 / \mathrm{cncr} .10272$

182. David H, Mendoza S, Konishi T, Miller CW. Simian virus 40 is present in human lymphomas and normal blood. Cancer Lett. (2001) 162:57-64. doi: 10.1016/S0304-3835(00)00628-5

183. Li R-M, Mannon RB, Kleiner D, Tsokos M, Bynum M, Kirk AD, et al. BK virus and SV40 co-infection in polyomavirus nephropathy. Transplantation. (2002) 74:1497-504. doi: 10.1097/00007890-200212150-00004

184. Li R-M, Branton MH, Tanawattanacharoen S, Falk RA, Jennette JC, Kopp JB. Molecular identification of SV40 infection in human subjects and possible association with kidney disease. J Am Soc Nephrol. (2002) 13:2320-30. doi: 10.1097/01.ASN.0000028249.06596.CF

185. Martini F, De Mattei M, Iaccheri L, Lazzarin L, Barbanti-Brodano G, Tognon $\mathrm{M}$, et al. Human brain tumors and simian virus 40. J Natl Cancer Inst. (1995) 87:1331. doi: 10.1093/jnci/87.17.1331 
186. Yamamoto H, Nakayama T, Murakami H, Hosaka T, Nakamata T, Tsuboyama T, et al. High incidence of SV40-like sequences detection in tumour and peripheral blood cells of Japanese osteosarcoma patients. $\mathrm{Br} \mathrm{J}$ Cancer. (2000) 82:1677-81. doi: 10.1054/bjoc.2000.1213

187. Pancaldi C, Balatti V, Guaschino R, Vaniglia F, Corallini A, Martini F, et al. Simian virus 40 sequences in blood specimens from healthy individuals of Casale Monferrato, an industrial town with a history of asbestos pollution. $J$ Infect. (2009) 58:53-60. doi: 10.1016/j.jinf.2008.10.014

188. Vanchiere JA, Nicome RK, Greer JM, Demmler GJ, Butel JS. Frequent detection of polyomaviruses in stool samples from hospitalized children. $J$ Infect Dis. (2005) 192:658-64. doi: 10.1086/432076

189. Minor P, Pipkin PA, Cutler K, Dunn G. Natural infection and transmission of SV40. Virology. (2003) 314:403-9. doi: 10.1016/S0042-6822(03)00435-5

190. Mazzoni E, Frontini F, Rotondo JC, Zanotta N, Fioravanti A, Minelli F, et al. Antibodies reacting to mimotopes of Simian virus 40 large $\mathrm{T}$ antigen, the viral oncoprotein, in sera from children. J Cell Physiol. (2018) 234:3170-9. doi: $10.1002 /$ jcp. 27490

191. Corallini A, Mazzoni E, Taronna A, Manfrini M, Carandina G, Guerra $\mathrm{G}$, et al. Specific antibodies reacting with simian virus 40 capsid protein mimotopes in serum samples from healthy blood donors. Hum Immunol. (2012) 73:502-10. doi: 10.1016/j.humimm.2012.02.009

192. Tognon M, Corallini A, Manfrini M, Taronna A, Butel JS, Pietrobon S, et al. Specific antibodies reacting with SV40 large $\mathrm{T}$ antigen mimotopes in serum samples of healthy subjects. PLOS ONE. (2016) 11:e0145720. doi: 10.1371/journal.pone.0145720

193. Taronna A, Mazzoni E, Corallini A, Bononi I, Pietrobon S, Guerra G, et al. Serological evidence of an early seroconversion to Simian virus 40 in healthy children and adolescents. PLoS ONE. (2013) 8:e61182. doi: 10.1371/journal.pone.0061182

194. Mazzoni E, Tognon M, Martini F, Taronna A, Corallini A, Barbanti-Brodano $\mathrm{G}$, et al. Simian virus 40 (SV40) antibodies in elderly subjects. J Infect. (2013) 67:356-8. doi: 10.1016/j.jinf.2013.06.002

195. Mazzoni E, Guerra G, Casali MV, Pietrobon S, Bononi I, Puozzo A, et al. Antibodies against mimotopes of simian virus 40 large $\mathrm{T}$ antigen, the oncoprotein, in serum samples from elderly healthy subjects. J Cell Physiol. (2017) 232:176-81. doi: 10.1002/jcp.25405

196. Comar M, Wong C, Tognon M, Butel JS. Neutralizing and IgG antibodies against simian virus 40 in healthy pregnant women in Italy. PLoS ONE. (2014) 9:e110700. doi: 10.1371/journal.pone.0110700

197. Mazzoni E, Di Stefano M, Fiore JR, Destro F, Manfrini M, Rotondo JC, et al. Serum IgG antibodies from pregnant women reacting to mimotopes of simian virus 40 large $\mathrm{T}$ antigen, the viral oncoprotein. Front Immunol. (2017) 8:411. doi: 10.3389/fimmu.2017.00411

198. Lundstig A, Eliasson L, Lehtinen M, Sasnauskas K, Koskela P, Dillner J. Prevalence and stability of human serum antibodies to simian virus 40 VP1 virus-like particles. J Gen Virol. (2005) 86(Pt 6):1703-8. doi: 10.1099/vir.0.80783-0

199. Stolt A, Sasnauskas K, Koskela P, Lehtinen M, Dillner J. Seroepidemiology of the human polyomaviruses. J Gen Virol. (2003) 84(Pt 6):1499-504. doi: 10.1099/vir.0.18842-0

200. Basetse HR, Lecatsas G, Gerber LJ. An investigation of the occurrence of SV40 antibodies in South Africa. S Afr Med J. (2002) 92:825-8.

201. Rollison DEM, Helzlsouer KJ, Alberg AJ, Hoffman S, Hou J, Daniel R, et al. Serum antibodies to JC virus, BK virus, simian virus 40, and the risk of incident adult astrocytic brain tumors. Cancer Epidemiol Biomarkers Prev. (2003) 12:460-3.

202. Kean JM, Rao S, Wang M, Garcea RL. Seroepidemiology of human polyomaviruses. PLoS Pathog. (2009) 5:e1000363. doi: 10.1371/journal.ppat.1000363

203. Butel JS, Wong C, Vilchez RA, Szücs G, Dömök I, Kríz B, et al. Detection of antibodies to polyomavirus SV40 in two central European countries. Cent Eur J Public Health. (2003) 11:3-8.

204. de Sanjose S, Shah KV, Domingo-Domenech E, Engels EA, Fernandez de Sevilla A, Alvaro T, et al. Lack of serological evidence for an association between simian virus 40 and lymphoma. Int J Cancer. (2003) 104:522-4. doi: 10.1002/ijc.11326

205. Jafar S, Rodriguez-Barradas M, Graham DY, Butel JS. Serological evidence of SV40 infections in HIV-infected and HIV-negative adults. J Med Virol. (1998) 54:276-84. doi: 10.1002/(SICI)1096-9071(199804)54:4<276::AID-JMV7>3.0.CO;2-1

206. Shah KV, Ozer HL, Pond HS, Palma LD, Murphy GP. SV40 neutralizing antibodies in sera of US residents without history of polio immunization. Nature. (1971) 231:448-9. doi: 10.1038/231448a0

207. Geissler E, Konzer P, Scherneck S, Zimmermann W. Sera collected before introduction of contaminated polio vaccine contain antibodies against SV40. Acta Virol. (1985) 29:420-3.

208. Viscidi RP, Rollison DEM, Viscidi E, Clayman B, Rubalcaba E, Daniel $\mathrm{R}$, et al. Serological cross-reactivities between antibodies to simian virus 40, BK virus, and JC virus assessed by virus-like-particle-based enzyme immunoassays. Clin Diagn Lab Immunol. (2003) 10:278-85. doi: 10.1128/CDLI.10.2.278-285.2003

209. Borgna-Pignatti C, Mazzoni E, Felletti M, Turlà G, Malaventura C, Cappellini MD, et al. Antibodies reacting with Simian virus 40 mimotopes in serum samples from patients with thalassaemia major. Blood Transfus. (2014) 12:464-70. doi: 10.2450/2013.0220-13

210. Wong C, Vilchez RA, Quiroz J, Adam E, Butel JS. Ethnic differences in polyomavirus simian virus 40 seroprevalence among women in Houston, Texas. J Infect. (2013) 66:67-74. doi: 10.1016/j.jinf.2012.08.014

211. Martini F, Mazzoni E, Corallini A, Taronna A, Querzoli P, Magri E, et al. Breast cancer and simian virus 40 infection. Epidemiology. (2013) 24:464-5. doi: 10.1097/EDE.0b013e31828d3ae6

212. Krieg P, Amtmann E, Jonas D, Fischer H, Zang K, Sauer G. Episomal simian virus 40 genomes in human brain tumors. Proc Natl Acad Sci USA. (1981) 78:6446-50. doi: 10.1073/pnas.78.10.6446

213. Zhen HN, Zhang X, Bu XY, Zhang ZW, Huang WJ, Zhang P, et al. Expression of the simian virus 40 large tumor antigen (Tag) and formation of Tag-p53 and Tag-pRb complexes in human brain tumors. Cancer. (1999) 86:212432. doi: 10.1002/(SICI)1097-0142(19991115)86:10<2124::AID-CNCR34>3. $0 . \mathrm{CO} ; 2-\mathrm{D}$

214. Huang H, Reis R, Yonekawa Y, Lopes JM, Kleihues P, Ohgaki H. Identification in human brain tumors of DNA sequences specific for SV40 large $\mathrm{T}$ antigen. Brain Pathol. (1999) 9:33-42. doi: 10.1111/j.1750-3639.1999.tb00207.x

215. Wang J, Garcea RL. Simian virus 40 DNA sequences in human brain and bone tumours. Dev Biol Stand. (1998) 94:13-21.

216. Martini F, Cultrera R, Contini C, Tognon M. Simian virus 40 sequences in an AIDS patient with a cerebral lesion: a case report. Scand J Infect Dis. (2006) 38:731-3. doi: 10.1080/00365540500372911

217. Suzuki SO, Mizoguchi M, Iwaki T. Detection of SV40 T antigen genome in human gliomas. Brain Tumor Pathol. (1997) 14:125-9. doi: 10.1007/BF02478881

218. Mazzoni E, Gerosa M, Lupidi F, Corallini A, Taronna AP, D’Agostino A, et al. Significant prevalence of antibodies reacting with simian virus 40 mimotopes in sera from patients affected by glioblastoma multiforme. Neuro Oncol. (2014) 16:513-9. doi: 10.1093/neuonc/not217

219. Wang Z, Hao Y, Zhang C, Wang Z, Liu X, Li G, et al. The landscape of viral expression reveals clinically relevant viruses with potential capability of promoting malignancy in lower-grade glioma. Clin Cancer Res. (2017) 23:2177-85. doi: 10.1158/1078-0432.CCR-16-1495

220. Arrington AS, Moore MS, Butel JS. SV40-positive brain tumor in scientist with risk of laboratory exposure to the virus. Oncogene. (2004) 23:2231-5. doi: 10.1038/sj.onc. 1207341

221. Ibelgaufts H, Jones KW. Papovavirus-related RNA sequences in human neurogenic tumours. Acta Neuropathol. (1982) 56:118-22. doi: 10.1007/BF00690582

222. Campello C, Comar M, Zanotta N, Minicozzi A, Rodella L, Poli A. Detection of SV40 in colon cancer: a molecular case-control study from northeast Italy. J Med Virol. (2010) 82:1197-200. doi: 10.1002/jmv.21798

223. Mazzoni E, Martini F, Corallini A, Taronna A, Barbanti-Brodano G, Querzoli P, et al. Serologic investigation of undifferentiated nasopharyngeal carcinoma and simian virus 40 infection. Head Neck. (2016) 38:232-6. doi: 10.1002/hed.23879

224. Lednicky JA, Stewart AR, Jenkins JJ, Finegold MJ, Butel JS. SV40 DNA in human osteosarcomas shows sequence variation among T-antigen genes. Int $J$ Cancer. (1997) 72:791-800. doi: 10.1002/(SICI) 1097-0215(19970904)72:5<791::AID-IJC15>3.0.CO;2-C 
225. Mazzoni E, Benassi MS, Corallini A, Barbanti-Brodano G, Taronna A, Picci P, et al. Significant association between human osteosarcoma and simian virus 40. Cancer. (2015) 121:708-15. doi: 10.1002/cncr.29137

226. Heinsohn S, Szendroi M, Bielack S, Stadt UZ, Kabisch H. Evaluation of SV40 in osteosarcoma and healthy population: a Hungarian-German study. Oncol Rep. (2009) 21:289-97. doi: 10.3892/or_00000220

227. Galateau-Salle F, Bidet P, Iwatsubo Y, Gennetay E, Renier A, Letourneux $M$, et al. Detection of SV40-like DNA sequences in pleural mesothelioma, bronchopulmonary carcinoma and other pulmonary diseases. Dev Biol Stand. (1998) 94:147-52. doi: 10.1002/(SICI)1096-9896(199803)184:3<252::AID-PATH15>3.3.CO;2-I

228. Priftakis P, Bogdanovic G, Hjerpe A, Dalianis T. Presence of simian virus 40 (SV40) is not frequent in Swedish malignant mesotheliomas. Anticancer Res. (2002) 22:1357-60.

229. McLaren BR, Haenel T, Stevenson S, Mukherjee S, Robinson BW, Lake RA. Simian virus (SV) 40 like sequences in cell lines and tumour biopsies from Australian malignant mesotheliomas. Aust N Z J Med. (2000) 30:450-6. doi: 10.1111/j.1445-5994.2000.tb02050.x

230. Carbone M, Pass HI, Rizzo P, Marinetti M, Di Muzio M, Mew DJ, et al. Simian virus 40-like DNA sequences in human pleural mesothelioma. Oncogene. (1994) 9:1781-90.

231. Griffiths DJ, Nicholson AG, Weiss RA. Detection of SV40 sequences in human mesothelioma. Dev Biol Stand. (1998) 94:127-36.

232. Comar M, Rizzardi C, de Zotti R, Melato M, Bovenzi M, Butel JS, et al. SV40 multiple tissue infection and asbestos exposure in a hyperendemic area for malignant mesothelioma. Cancer Res. (2007) 67:8456-9. doi: 10.1158/0008-5472.CAN-07-2232

233. Ramael M, Nagels J, Heylen H, De Schepper S, Paulussen J, De Maeyer M, et al. Detection of SV40 like viral DNA and viral antigens in malignant pleural mesothelioma. Eur Respir J. (1999) 14:1381-6. doi: 10.1183/09031936.99.14613819

234. Ramael M, Nagels J. Re. SV40-like DNA sequences in pleural mesothelioma, bronchopulmonary carcinoma and non-malignant pulmonary disease. J Pathol. (1999) 189:628-9. doi: 10.1002/(SICI)10969896(199912)189:4<628::AID-PATH481>3.0.CO;2-5

235. De Rienzo A, Tor M, Sterman DH, Aksoy F, Albelda SM, Testa JR. Detection of SV40 DNA sequences in malignant mesothelioma specimens from the United States, but not from Turkey. J Cell Biochem. (2002) 84:455-9. doi: $10.1002 /$ jcb. 10058

236. Cristaudo A, Foddis R, Vivaldi A, Buselli R, Gattini V, Guglielmi G, et al. SV40 enhances the risk of malignant mesothelioma among people exposed to asbestos: a molecular epidemiologic case-control study. Cancer Res. (2005) 65:3049-52. doi: 10.1158/0008-5472.CAN-04-2219

237. Mazzoni E, Corallini A, Cristaudo A, Taronna A, Tassi G, Manfrini M, et al. High prevalence of serum antibodies reacting with simian virus 40 capsid protein mimotopes in patients affected by malignant pleural mesothelioma. Proc Natl Acad Sci USA. (2012) 109:18066-71. doi: 10.1073/pnas.1213238109

238. Zekri A-RN, Bahnassy AA, Mohamed WS, Hassan N, Abdel-Rahman A-RM, El-Kassem FA, et al. Evaluation of simian virus-40 as a biological prognostic factor in Egyptian patients with malignant pleural mesothelioma. Pathol Int. (2007) 57:493-501. doi: 10.1111/j.1440-1827.2007.02130.x

239. Zekri A-R, Mohamed W, Bahnassy A, Refat L, Khaled M, Shalaby S, et al. Detection of simian virus 40 DNA sequences in Egyptian patients with different hematological malignancies. Leuk Lymphoma. (2007) 48:1828-34. doi: 10.1080/10428190701534408

240. Gordon GJ, Chen C-J, Jaklitsch MT, Richards WG, Sugarbaker DJ, Bueno R. Detection and quantification of SV40 large T-antigen DNA in mesothelioma tissues and cell lines. Oncol Rep. (2002) 9:631-4. doi: 10.3892/or.9.3.631

241. Jin M, Sawa H, Suzuki T, Shimizu K, Makino Y, Tanaka S, et al. Investigation of simian virus 40 large $\mathrm{T}$ antigen in 18 autopsied malignant mesothelioma patients in Japan. J Med Virol. (2004) 74:668-76. doi: 10.1002/jmv.20219

242. Pepper C, Jasani B, Navabi H, Wynford-Thomas D, Gibbs AR. Simian virus 40 large $\mathrm{T}$ antigen (SV40LTAg) primer specific DNA amplification in human pleural mesothelioma tissue. Thorax. (1996) 51:1074-6. doi: $10.1136 /$ thx.51.11.1074

243. Shivapurkar N, Wiethege T, Wistuba II, Salomon E, Milchgrub S, Muller KM, et al. Presence of simian virus 40 sequences in malignant mesotheliomas and mesothelial cell proliferations. J Cell Biochem. (1999) 76:181-8. doi: 10.1002/(SICI)1097-4644(20000201)76:2<181::AID-JCB2>3.3.CO;2-0

244. Pacini F, Vivaldi A, Santoro M, Fedele M, Fusco A, Romei C, et al. Simian virus 40-like DNA sequences in human papillary thyroid carcinomas. Oncogene. (1998) 16:665-9. doi: 10.1038/sj.onc.1201552

245. Loghavi S, Bose S. Polyomavirus infection and urothelial carcinoma. Diagn Cytopathol. (2011) 39:531-5. doi: 10.1002/dc.21490

246. Bononi I, Perri P, Begnardi A, Martini A, Mazzoni E, Bosi S, et al. Antibodies reacting with Simian Virus 40 capsid protein mimotopes in serum samples from patients affected by uveal melanoma. J Hematol Oncol. (2014) 7:38. doi: 10.1186/1756-8722-7-38

247. Vilchez RA, Lednicky JA, Halvorson SJ, White ZS, Kozinetz CA, Butel JS. Detection of polyomavirus simian virus 40 tumor antigen DNA in AIDSrelated systemic non-Hodgkin lymphoma. J Acquir Immune Defic Syndr. (2002) 29:109-16. doi: 10.1097/00042560-200202010-00001

248. Rizzo P, Carbone M, Fisher SG, Matker C, Swinnen LJ, Powers A, et al. Simian virus 40 is present in most United States human mesotheliomas, but it is rarely present in non-Hodgkin's lymphoma. Chest. (1999) 116(6 Suppl.):470S-473S. doi: 10.1378/chest.116.suppl_3.470S

249. Shivapurkar N, Harada K, Reddy J, Scheuermann RH, Xu Y, McKenna RW, et al. Presence of simian virus 40 DNA sequences in human lymphomas. Lancet. (2002) 359:851-2. doi: 10.1016/S0140-6736(02)07921-7

250. Vilchez RA, Madden CR, Kozinetz CA, Halvorson SJ, White ZS, Jorgensen $\mathrm{JL}$, et al. Association between simian virus 40 and non-Hodgkin lymphoma. Lancet. (2002) 359:817-23. doi: 10.1016/S0140-6736(02)07950-3

251. Vilchez RA, Lopez-Terrada D, Middleton JR, Finch CJ, Killen DE, Zanwar $\mathrm{P}$, et al. Simian virus 40 tumor antigen expression and immunophenotypic profile of AIDS-related non-Hodgkin's lymphoma. Virology. (2005) 342:3846. doi: 10.1016/j.virol.2005.06.053

252. Tognon M, Luppi M, Corallini A, Taronna A, Barozzi P, Rotondo JC, et al. Immunologic evidence of a strong association between nonHodgkin lymphoma and simian virus 40. Cancer. (2015) 121:2618-26. doi: 10.1002/cncr.29404

253. Mazzoni E, Pietrobon S, Bilancia M, Vinante F, Rigo A, Ferrarini I, et al. High prevalence of antibodies reacting to mimotopes of Simian virus 40 large $\mathrm{T}$ antigen, the oncoprotein, in serum samples of patients affected by non-Hodgkin lymphoma. Cancer Immunol Immunother. (2017) 66:1189-98. doi: 10.1007/s00262-017-2008-9

254. Amara K, Trimeche M, Ziadi S, Laatiri A, Hachana M, Sriha B, et al. Presence of simian virus 40 DNA sequences in diffuse large B-cell lymphomas in Tunisia correlates with aberrant promoter hypermethylation of multiple tumor suppressor genes. Int J Cancer. (2007) 121:2693-702. doi: $10.1002 /$ ijc. 23038

255. Heinsohn S, Scholz R, Kabisch H. SV40 and p53 as team players in childhood lymphoproliferative disorders. Int J Oncol. (2011) 38:1307-17. doi: 10.3892/ijo.2011.967

256. Restrepo CS, Chen MM, Martinez-Jimenez S, Carrillo J, Restrepo C. Chest neoplasms with infectious etiologies. World J Radiol. (2011) 3:279-88. doi: 10.4329/wjr.v3.i12.279

257. Pass HI, Donington JS, Wu P, Rizzo P, Nishimura M, Kennedy R, et al. Human mesotheliomas contain the simian virus-40 regulatory region and large tumor antigen DNA sequences. J Thorac Cardiovasc Surg. (1998) 116:854-9. doi: 10.1016/S0022-5223(98)00438-3

258. Cristaudo A, Vivaldi A, Sensales G, Guglielmi G, Ciancia E, Elisei R, et al. Molecular biology studies on mesothelioma tumor samples: preliminary data on H-ras, p21, and SV40. J Environ Pathol Toxicol Oncol. (1995) 14:29-34.

259. Butel JS. Increasing evidence for involvement of SV40 in human cancer. Dis Markers. (2001) 17:167-72. doi: 10.1155/2001/857621

260. Vilchez RA, Butel JS. SV40 in human brain cancers and non-Hodgkin's lymphoma. Oncogene. (2003) 22:5164-72. doi: 10.1038/sj.onc.1206547

261. Jensen F, Koprowski H, Pagano JS, Pontén J, Ravdin RG. Autologous and homologous implantation of human cells transformed in vitro by simian virus. J Natl Cancer Inst. (1964) 32:917-37.

262. López-Ríos F, Illei PB, Rusch V, Ladanyi M. Evidence against a role for SV40 infection in human mesotheliomas and high risk of false-positive PCR results owing to presence of SV40 sequences in common laboratory plasmids. Lancet. (2004) 364:1157-66. doi: 10.1016/S0140-6736(04)17102-X 
263. Mayall F, Barratt K, Shanks J. The detection of Simian virus 40 in mesotheliomas from New Zealand and England using real time FRET probe PCR protocols. J Clin Pathol. (2003) 56:728-30. doi: 10.1136/jcp.56.10.728

264. Rizzo P, Bocchetta M, Powers A, Foddis R, Stekala E, Pass HI, et al. SV40 and the pathogenesis of mesothelioma. Semin Cancer Biol. (2001) 11:63-71. doi: $10.1006 /$ scbi.2000.0347

265. Gaudino G, Yang H, Carbone M. HGF/Met signaling is a key player in malignant mesothelioma carcinogenesis. Biomedicines. (2014) 2:327-44. doi: 10.3390/biomedicines2040327

266. Governa M, Amati M, Bellis D, Bichisecchi E, Santarelli L. Diagnosis of asbestos-related pleuropolmonary diseases. Med Lav. (2006) 97:463-74.

267. Leithner A, Weinhaeusel A, Windhager R, Schlegl R, Waldner P, Lang S, et al. Absence of SV40 in Austrian tumors correlates with low incidence of mesotheliomas. Cancer Biol Ther. (2002) 1:375-9. doi: 10.4161/cbt.1.4.10

268. Aoe K, Hiraki A, Murakami T, Toyooka S, Shivapurkar N, Gazdar $\mathrm{AF}$, et al. Infrequent existence of simian virus 40 large $\mathrm{T}$ antigen DNA in malignant mesothelioma in Japan. Cancer Sci. (2006) 97:292-5. doi: 10.1111/j.1349-7006.2006.00171.x

269. Comar M, Zanotta N, Bovenzi M, Campello C. JCV/BKV and SV40 viral load in lymphoid tissues of young immunocompetent children from an area of north-east Italy. J Med Virol. (2010) 82:1236-40. doi: 10.1002/jmv.21786

270. Cacciotti P, Strizzi L, Vianale G, Iaccheri L, Libener R, Porta C, et al. The presence of simian-virus 40 sequences in mesothelioma and mesothelial cells is associated with high levels of vascular endothelial growth factor. Am J Respir Cell Mol Biol. (2002) 26:189-93. doi: 10.1165/ajrcmb.26.2.4673

271. Catalano A, Romano M, Martinotti S, Procopio A. Enhanced expression of vascular endothelial growth factor (VEGF) plays a critical role in the tumor progression potential induced by simian virus 40 large T antigen. Oncogene. (2002) 21:2896-900. doi: 10.1038/sj.onc.1205382

272. Porcu P, Ferber A, Pietrzkowski Z, Roberts CT, Adamo M, LeRoith D, et al. The growth-stimulatory effect of simian virus $40 \mathrm{~T}$ antigen requires the interaction of insulinlike growth factor 1 with its receptor. Mol Cell Biol. (1992) 12:5069-77. doi: 10.1128/MCB.12.11.5069

273. Reeve JG, Guadaño A, Xiong J, Morgan J, Bleehen NM. Diminished expression of insulin-like growth factor (IGF) binding protein-5 and activation of IGF-I-mediated autocrine growth in simian virus 40-transformed human fibroblasts. J Biol Chem. (1995) 270:135-42. doi: $10.1074 /$ jbc.270.1.135

274. Liu J, Li H, Nomura K, Dofuku R, Kitagawa T. Cytogenetic analysis of hepatic cell lines derived from SV40-T antigen geneharboring transgenic mice. Cancer Genet Cytogenet. (1991) 55:207-16. doi: 10.1016/0165-4608(91)90079-A

275. Strickler HD, Goedert JJ, Fleming M, Travis WD, Williams AE, Rabkin CS, et al. Simian virus 40 and pleural mesothelioma in humans. Cancer Epidemiol Biomarkers Prev. (1996) 5:473-5.

276. Strickler HD, International SV40 Working Group. A multicenter evaluation of assays for detection of SV40 DNA and results in masked mesothelioma specimens. Cancer Epidemiol Biomarkers Prev. (2001) 10:523-32.

277. Engels EA, Sarkar C, Daniel RW, Gravitt PE, Verma K, Quezado M, et al. Absence of simian virus 40 in human brain tumors from northern India. Int J Cancer. (2002) 101:348-52. doi: 10.1002/ijc.10621
278. Gee GV, Stanifer ML, Christensen BC, Atwood WJ, Ugolini D, Bonassi S, et al. SV40 associated miRNAs are not detectable in mesotheliomas. $\mathrm{Br} \mathrm{J}$ Cancer. (2010) 103:885-8. doi: 10.1038/sj.bjc.6605848

279. Manfredi JJ, Dong J, Liu W, Resnick-Silverman L, Qiao R, Chahinian P, et al. Evidence against a role for SV40 in human mesothelioma. Cancer Res. (2005) 65:2602-9. doi: 10.1158/0008-5472.CAN-04-2461

280. Mazzoni E, Bononi I, Benassi MS, Picci P, Torreggiani E, Rossini M, et al. Serum antibodies against simian virus 40 large $\mathrm{T}$ antigen, the viral oncoprotein, in osteosarcoma patients. Front Cell Dev Biol. (2018) 6:64. doi: 10.3389/fcell.2018.00064

281. Mazzoni E, Pietrobon S, Masini I, Rotondo JC, Gentile M, Fainardi $\mathrm{E}$, et al. Significant low prevalence of antibodies reacting with simian virus 40 mimotopes in serum samples from patients affected by inflammatory neurologic diseases, including multiple sclerosis. PLoS ONE. (2014) 9:e110923. doi: 10.1371/journal.pone.01 10923

282. Fainardi E, Bortolotti D, Bolzani S, Castellazzi M, Tamborino C, Roversi G, et al. Cerebrospinal fluid amounts of HLA-G in dimeric form are strongly associated to patients with MRI inactive multiple sclerosis. Mult Scler. (2016) 22:245-9. doi: 10.1177/1352458515590647

283. Rizzo R, Pietrobon S, Mazzoni E, Bortolotti D, Martini F, Castellazzi $\mathrm{M}$, et al. Serum IgG against Simian Virus 40 antigens are hampered by high levels of sHLA-G in patients affected by inflammatory neurological diseases, as multiple sclerosis. J Transl Med. (2016) 14:216. doi: 10.1186/s12967-016-0981-y

284. Milstone A, Vilchez RA, Geiger X, Fogo AB, Butel JS, Dummer S. Polyomavirus simian virus 40 infection associated with nephropathy in a lung-transplant recipient. Transplantation. (2004) 77:1019-24. doi: 10.1097/01.TP.0000119156.52197.CA

285. Wong C, Zhang S, Adam E, Paszat L, Butel JS. SV40 seroprevalence in two Latin American countries involved in field trials of candidate oral poliovaccines. J Infect. (2019) 78:476-83. doi: 10.1016/j.jinf.2019.04.007

286. Scuda N, Hofmann J, Calvignac-Spencer S, Ruprecht K, Liman P, Kühn $\mathrm{J}$, et al. A novel human polyomavirus closely related to the African green monkey-derived lymphotropic polyomavirus. J Virol. (2011) 85:4586-90. doi: 10.1128/JVI.02602-10

287. zur Hausen H, Gissmann L. Lymphotropic papovaviruses isolated from African green monkey and human cells. Med Microbiol Immunol. (1979) 167:137-53. doi: 10.1007/BF02121180

Conflict of Interest Statement: The authors declare that the research was conducted in the absence of any commercial or financial relationships that could be construed as a potential conflict of interest.

Copyright (C) 2019 Rotondo, Mazzoni, Bononi, Tognon and Martini. This is an openaccess article distributed under the terms of the Creative Commons Attribution License (CC BY). The use, distribution or reproduction in other forums is permitted, provided the original author(s) and the copyright owner(s) are credited and that the original publication in this journal is cited, in accordance with accepted academic practice. No use, distribution or reproduction is permitted which does not comply with these terms. 